\title{
Hardly Flammable Polyurethane Foams with 1,3-Pyrimidine Ring and Boron Atoms
}

\author{
Elżbieta Chmiel-Szukiewicz
}

Citation: Chmiel-Szukiewicz, E. Hardly Flammable Polyurethane Foams with 1,3-Pyrimidine Ring and Boron Atoms. Polymers 2021, 13, 1603. https://doi.org/10.3390/ polym 13101603

Academic Editor: Ugis Cābulis

Received: 20 April 2021

Accepted: 12 May 2021

Published: 16 May 2021

Publisher's Note: MDPI stays neutral with regard to jurisdictional claims in published maps and institutional affiliations.

Copyright: (C) 2021 by the author. Licensee MDPI, Basel, Switzerland. This article is an open access article distributed under the terms and conditions of the Creative Commons Attribution (CC BY) license (https:/ / creativecommons.org/licenses/by/ $4.0 /)$.
Department of Organic Chemistry, Faculty of Chemistry, Rzeszow University of Technology, al. Powstańców Warszawy 6, 35-959 Rzeszów, Poland; szukela@prz.edu.pl

\begin{abstract}
This work presents the results of research related to the determination of application possibilities of new oligoetherols with 1,3-pyrimidine rings and boron atoms in rigid polyurethane foam production. Oligoetherols were obtained from 1,3-bis(2-hydroxyethyl)uracil, boric acid, and ethylene carbonate. Their structure was determined by instrumental methods (IR, ${ }^{1} \mathrm{H}-\mathrm{NMR}$ and MALDI-ToF spectra) and the physicochemical and thermal properties were examined. Obtained oligoetherols were used for synthesis of polyurethane foams. Some properties of the foams, such as apparent density, water uptake, dimensions stability, thermal stability, compression strength, thermal conductivity, oxygen index, and horizontal burning were investigated. The introduction of boron atoms into the foam structure reduced their flammability, but unfortunately it had a negative effect on the water absorption of the obtained materials-the water absorption was higher compared to the boron-free foams. The obtained foams showed good thermal stability compared to classic, rigid polyurethane foams.
\end{abstract}

Keywords: rigid polyurethane foams; flammability; thermal stability; 1,3-pyrimidine ring; 1,3-bis(2hydroxyethyl)uracil; boric acid; ethylene carbonate

\section{Introduction}

Polyurethanes are polymeric materials which, thanks to their physicochemical properties, have been widely used in all areas of technology and economy. Among polyurethane plastics, foams are of great technological importance. They represent two thirds of the world's production of polyurethanes [1]. The growing ecological awareness, combined with the size of polyurethane production, make it necessary to replace synthetic ingredients with natural or recycled ingredients. For this reason, there is a trend in the production of polyurethanes, including polyurethane foams, of using the polyols obtained from vegetable oils or from recycled products, e.g., polyethylene terephthalate [2-10]. Such foams have properties similar or better than the commercial foams available on the market. The foams based on bio-polyol are characterized by low water absorption (up to $2 \%$ after $24 \mathrm{~h}$ ), low thermal conductivity (about $25 \mathrm{~mW} /(\mathrm{m} \times \mathrm{K})$ ), and good compressive strength (up to $0.3 \mathrm{MPa}$ ) [2,8-10]. Good mechanical properties are demonstrated by the foams obtained from polyols based on rapeseed oil and recycled polyethylene terephthalate [9].

Polyurethane foam plastics are currently the most widely used insulating material. This is a result of their advantages, such as lower thermal conductivity coefficients than polystyrene and, additionally, they are light, durable, and easy to install. The main disadvantages of foams plastics are low thermal resistance and relatively low decomposition temperature. The thermal resistance of typical polyurethane foams usually does not exceed $120^{\circ} \mathrm{C}$ [11], and the degradation of polyurethane foams is accompanied by the formation of flammable substances, which creates a fire hazard. In the course of burning, polyurethanes emit toxic gases, among others hydrogen cyanide, carbon monoxide and carbon dioxide, and nitrogen oxides [12,13]. This is a danger to human life and health, and for this reason methods to reduce the flammability of polyurethane foams and improve their thermal 
resistance are sought. Foams of improved thermal stability can be obtained by using an oligo- or polyetherol component containing some heterocyclic rings (Scheme 1), e.g., 1,3,5-triazine (I) [14,15], purine (II) [16,17], or 1,3-pyrimidine (III) [18-21].<smiles>[R]N(O)c1nc(N([R])O)nc(N([R])O)n1</smiles>

(I)<smiles>[R]n1c(=O)c2c(n([R])c1=O)n([R])c(=O)n2O</smiles>

(II)<smiles>[R]N(O)c1cc(=O)n([R])c(=O)n1O</smiles>

(III)

Scheme 1. General structure of oligoetherols with 1,3,5-triazine (I), purine (II), and 1,3-pyrimidine (III) rings.

Foams containing these heterocyclic rings in their structure are resistant to long-term heat exposure up to $200{ }^{\circ} \mathrm{C}$, but unfortunately, they are flammable. This is a disadvantage, especially for thermal insulation materials that are to be used at high temperatures. Therefore, polyurethane foams are subjected to modifications increasing their fire resistance. One of the methods of reducing the flammability of polyurethane plastics consists in introducing atoms into the foam structure that impede the burning, e.g., nitrogen, phosphorus, silicon, or boron [22-24]. Currently, the use of halogen flame retardants is being abandoned due to their negative impact on people and the environment [25].

Quite common reactive flame retardants for polyurethane foams are organic esters of boric acid, which are polyol components in the synthesis of foams [26-29]. The use of oligoand polyetherols with boron atoms and heterocyclic rings, e.g., perhydro-1,3,5-triazine or 1,3,5-triazine rings, allows obtaining foams with improved thermal stability and reduced flammability [30-33].

This paper proposes the syntheses of polyurethane foams with the use of oligoetherols obtained in the reactions of 1,3-bis(2-hydroxyethyl)uracil (BHEU) with boric acid (BA) and ethylene carbonate (EC). Two methods for the synthesis of oligoetherols are presented; their structures were determined and selected properties were examined. Properties of the foams obtained using the oligoetherols, such as thermal stability and flammability, were tested.

\section{Materials and Methods}

\subsection{Synthesis of 1,3-bis(2-hydroxyethyl)uracil}

BHEU was obtained from uracil (99\%, Alfa Aesar, Germany) and ethylene oxide (pure, Honeywell-Fluka, Buchs, Switzerland) according to the patent [34].

\subsection{Oligoetherols Synthesis}

\subsubsection{Two-Step Synthesis of Oligoetherol}

Reaction of BHEU with BA

First, $10.01 \mathrm{~g}(0.05 \mathrm{~mol})$ of BHEU and $6.2 \mathrm{~g}(0.1 \mathrm{~mol})$ of BA (pure, POCH, Gliwice, Poland) were placed in an open $100 \mathrm{~cm}^{3}$ three-necked flask, equipped with a mechanical stirrer and a thermometer. The contents of the flask were heated at $90-95{ }^{\circ} \mathrm{C}$ to melt the reactants, then $1 \mathrm{~cm}^{3}$ of distilled water was added to better homogenize the reactants. Then, the stirrer was started and the open flask was heated at $120^{\circ} \mathrm{C}$ for about $30-35 \mathrm{~min}$, until the appropriate weight loss associated with evaporation of the water formed in the reaction was reached. The obtained product (2,4-dioxopyrimidine-1,3-diethyl bis(dihydroborate), DOPDEDHB, elemental analysis: found: $32.93 \%$ C, $4.97 \% \mathrm{H}, 9.55 \% \mathrm{~N}$; calculated: $33.39 \%$ C, $4.90 \% \mathrm{H}, 9.74 \% \mathrm{~N}$ ) was a creamy, glassy mass. 


\section{Reactions of DOPDEDHB with EC}

To a three-necked flask equipped with a mechanical stirrer, reflux condenser and thermometer, containing $14.41 \mathrm{~g}$ (0.05 mol) of DOPDEDHB, $52.84 \mathrm{~g}(0.6 \mathrm{~mol})$ or $70.45 \mathrm{~g}$ $(0.8 \mathrm{~mol})$ of EC (pure, Honeywell-Fluka, Buchs, Switzerland) and $1 \mathrm{~g}$ of potassium carbonate as catalyst were added. After the reactants were melted $\left(90-95^{\circ} \mathrm{C}\right)$, the stirrer was started and the mixture was heated at $160{ }^{\circ} \mathrm{C}$ for $19(0.6 \mathrm{~mol} \mathrm{EC})$ or $33 \mathrm{~h}(0.8 \mathrm{~mol} \mathrm{EC})$. The end of the reaction was determined by analyzing the IR spectrum of the reactions mixture-the disappearance of the band at $1800 \mathrm{~cm}^{-1}$ of valence vibrations of carbonyl group $\mathrm{C}=\mathrm{O}$ of unreacted EC was used as the indicator.

\subsubsection{One-Pot Synthesis of Oligoetherol}

To a three-necked flask equipped with a mechanical stirrer, reflux condenser and thermometer $10.01 \mathrm{~g}(0.05 \mathrm{~mol})$ of BHEU, $6.2 \mathrm{~g}(0.1 \mathrm{~mol})$ or $9.3 \mathrm{~g}(0.15 \mathrm{~mol})$ of BA and $52.84 \mathrm{~g}(0.6 \mathrm{~mol})$ of EC were added. The contents of the flask were melted at $90-95^{\circ} \mathrm{C}$, then the stirrer was started and the mixture was heated for $4 \mathrm{~h}$ at $120^{\circ} \mathrm{C}$. After this time, $1 \mathrm{~g}$ potassium carbonate was added, the temperature was increased to $160^{\circ} \mathrm{C}$ and the mixture was heated for $38(0.1 \mathrm{~mol} \mathrm{BA})$ or $28(0.15 \mathrm{~mol} \mathrm{BA})$ hours. The end of the reaction was determined by analyzing the IR spectrum of reactions mixture- the disappearance of the band at $1800 \mathrm{~cm}^{-1}$ of valence vibrations of carbonyl group $\mathrm{C}=\mathrm{O}$ of unreacted EC was used as the indicator.

\subsection{Foams Synthesis}

A $10 \mathrm{~g}$ quantity of oligoetherol was introduced into a $500 \mathrm{~cm}^{3}$ polypropylene cup, then $1.95 \%$ silicone L-6900 (pure, Momentive Performance Materials, Wilton, CT, USA) as a surfactant, 2-3\% distillate water, and 2.16-4.86\% TEA (pure, Avantor Performance Materials Poland S.A., Gliwice, Poland) as a catalyst were added. The mixture was vigorously stirred and then polymeric 4, $4^{\prime}$-diphenylmethane diisocyanate (pMDI, mixture of di- and triisocyanates (30\%) for synthesis; Merck-Schuchardt, Hohenbrunn, Germany) was added (Table 1). The mixture was vigorously stirred until creaming started.

Table 1. The influence of composition on foaming process.

\begin{tabular}{|c|c|c|c|c|c|c|c|c|}
\hline \multirow{2}{*}{$\begin{array}{l}\text { Oligoetherol- } \\
\text { Product of } \\
\text { Reaction }\end{array}$} & \multirow[b]{2}{*}{$\begin{array}{l}\text { Composition } \\
\text { Number }\end{array}$} & \multicolumn{3}{|c|}{$\begin{array}{l}\text { Composition * } \\
\text { (g/100 g of Oligoetherol) }\end{array}$} & \multicolumn{3}{|c|}{ Foaming Process } & \multirow[b]{2}{*}{$\begin{array}{l}\text { Characteristics of Freshly } \\
\text { Prepared Foams }\end{array}$} \\
\hline & & pMDI & TEA & Water & $\begin{array}{l}\text { Time of } \\
\text { Creaming } \\
\text { (s) }\end{array}$ & $\begin{array}{l}\text { Time of } \\
\text { Expanding } \\
\text { (s) }\end{array}$ & $\begin{array}{l}\text { Time of } \\
\text { Drying } \\
\text { (s) }\end{array}$ & \\
\hline \multirow{2}{*}{$\begin{array}{c}\text { BHEU:BA:EC } \\
1: 2: 12\end{array}$} & 1 & 128 & 2.16 & 2 & 52 & 10 & 1 & \multirow{2}{*}{$\begin{array}{c}\text { insufficiently grown, hard } \\
\text { small shrink, small regular } \\
\text { pores, rigid }\end{array}$} \\
\hline & 2 & 149 & 2.70 & 3 & 46 & 17 & 1 & \\
\hline BHEU:BA:EC & 3 & 165 & 4.31 & 3 & 40 & 12 & 5 & rigid after time \\
\hline 1:3:12 & 4 & 160 & 3.77 & 3 & 43 & 9 & 1 & rigid \\
\hline \multirow[b]{2}{*}{$\begin{array}{c}\text { DOPDEDHB:EC } \\
1: 12\end{array}$} & 5 & 80 & 3.23 & 3 & 35 & 60 & 190 & unrigid \\
\hline & 6 & 120 & 4.86 & 3 & 25 & 43 & 1 & \multirow{2}{*}{$\begin{array}{c}\text { small shrink, small regular } \\
\text { pores, rigid } \\
\text { small regular pores, rigid }\end{array}$} \\
\hline & 7 & 140 & 3.85 & 3 & 32 & 20 & 1 & \\
\hline DOPDEDHB:EC & 8 & 120 & 4.31 & 3 & 79 & 23 & 1 & rigid after time \\
\hline $1: 16$ & 9 & 140 & 3.50 & 3 & 27 & 11 & 1 & small regular pores, rigid \\
\hline
\end{tabular}

* a constant amount of the surfactant (silicone) was used at 1.95/100 g oligoetherol.

\subsection{Analytical Methods}

The infrared spectra were registered on ALPHA FT-IR spectrometer, (Bruker, Ettlingen, Germany) ATR technique. The ${ }^{1} \mathrm{H}-\mathrm{NMR}$ spectra were recorded with a $500 \mathrm{MHz}$ Bruker UltraShield spectrometer in $\mathrm{d}_{6}$-DMSO with hexamethyldisiloxane as internal standard. Elemental analyses for $\mathrm{C}, \mathrm{H}$, and $\mathrm{N}$ of the product reaction of BHEU with BA were done with Vario EL III, Elementar Analyzer (Elementar, Langenseldbold, Germany). MALDIToF spectra (matrix-assisted laser desorption/ionization time of flight) were obtained on a Bruker autoflex speed reflectron time-of-flight mass spectrometer (Bruker, Ettlingen, 
Germany), equipped with a SmartBeam II laser (Bruker, Ettlingen, Germany) (352 nm) in $80-2000 \mathrm{~m} / \mathrm{z}$ range. Mass calibration was performed using internal standards (gold ions and clusters from $\mathrm{Au}^{+}$to $\mathrm{Au}_{10}{ }^{+}$depending on $\mathrm{m} / \mathrm{z}$ range). The sample solution (ca. $5 \mathrm{mg} / \mathrm{mL}$ in $\mathrm{H}_{2} \mathrm{O}$ ) was placed on AuNPET [35] $(0.5 \mu \mathrm{L})$ with a $0.5 \mu \mathrm{L}$ standard $\alpha$-cyano-4-hydroxycinnamic acid solution (1:1 water:acetonitrile with $0.2 \%$ TFA). The oligoetherols were also analyzed by gas chromatography with a Hewlett-Packard 4890A instrument (Agilent Technologies Deutschland GmbH, Waldbronn, Germany) equipped with a flame ionization detector. From chromatograms, the amounts of side products (glycols and polyglycols) formed in the reaction were determined. The gas chromatography conditions were as follows: HP-FFAP capillary column of $30 \mathrm{~m}$ length, $0.53 \mathrm{~mm}$ diameter, $1.5 \mu \mathrm{m}$ film thickness, port temperature: $220^{\circ} \mathrm{C}$, temperature profile: $50-220^{\circ} \mathrm{C}$, heating rate $20 \mathrm{deg} . / \mathrm{min}$, the helium flow $18.3 \mathrm{~cm}^{3} / \mathrm{min}$, and $0.2 \mu \mathrm{dm}^{3}$ sample volume. The calibration was performed with cyclohexanone ( $\geq 99 \%$, S.A. POCH, Gliwice, Poland) as an internal standard. A series of reference substances were used: ethylene glycol, diethylene glycol, triethylene glycol, and tetraethylene glycol, (pure Aldrich, UK). The percentages of glycols/polyglycols in products were determined based on calibration curves with the same internal standard using Equation (1):

$$
\frac{m_{g}}{m_{s t}}=a \times \frac{S_{g}}{S_{s t}}+b
$$

where: $m_{g}, m_{s t}:$ glycol/polyglycol mass and mass of standard, respectively; $S_{g}, S_{s t}$ : integrated peak area of glycol/polyglycol and standard, respectively; $a, b$ : experimental coefficients of calibration curves.

The mass of side products (glycols and polyglycols) were calculated from Formula (1). The amount of side products in mass percentage were calculated considering total sample mass $\left(m_{s}\right)$ according to Equation (2):

$$
\% G=\frac{m_{g}}{m_{s}} \times 100 \%
$$

Some other properties of the oligoetherols were evaluated, such as density (pycnometrically), viscosity (Höpler viscometer, type BHZ, VEB Prüfgerate-Werk Medingen, Freital, Germany), and surface tension, by the detaching ring method. The surface morphologies of foams were photo-recorded with Malvern's MORPHOLOGI G3 apparatus (Malvern Instruments Ltd., Malvern, UK)with 123 (zoom 2.5) and 247 (zoom 5.0) enhancement lenses. The thermal analysis of foams was conducted with a thermogravimetric analyzer TGA/DSC 1 (Mettler Toledo, Spain); the recording conditions were as follows: sample weight 2-4 mg, temperature range $25-600^{\circ} \mathrm{C}$, recording time $60 \mathrm{~min}$, and nitrogen atmosphere. Thermal resistance of foams was determined also by static method. The foams were heated for a month (during this time the foam mass stabilizes) at 150,175 , and $200{ }^{\circ} \mathrm{C}$ with continuous measurement of mass loss. Mass loss of foam was calculated from Equation (3):

$$
\Delta m=\frac{m_{0}-m_{t}}{m_{0}} \times 100 \%
$$

where: $m_{0}, m_{t}$ : mass of the sample before and after heated, respectively (g).

The apparent density of foams (the ratio of foam weight to its geometrical volume) was determined for cube-shaped samples according to the norm [36]. Water absorption was tested according to the norm [37] by immersing the samples in distilled water for $5 \mathrm{~min}, 3 \mathrm{~h}$, and $24 \mathrm{~h}$. Water absorption in vol \% was calculated from Equation (4):

$$
\% W_{A}=\frac{m_{2}-m_{1}}{V_{0} \times d_{W}} \times 100 \%
$$


where: $m_{1}, m_{2}$ : mass of the sample before and after immersion in distilled water, respectively $(\mathrm{g}), V_{0}$ : volume of the sample before immersion in distilled water $\left(\mathrm{cm}^{3}\right), \mathrm{d}_{\mathrm{W}}$ : density of distilled water $\left(d_{W}=1 \mathrm{~g} / \mathrm{cm}^{3}\right)$.

Linear dimension stability of foams was determined according to the norm [38] by thermostating the samples at a temperature $150{ }^{\circ} \mathrm{C}$ for 20 and $40 \mathrm{~h}$ and measuring changes in length $(\Delta l)$, width $(\Delta b)$, and thickness $(\Delta \delta)$ of samples (Equations (5)-(7)):

$$
\begin{gathered}
\Delta l=\frac{l_{1}-l_{0}}{l_{0}} \times 100 \% \\
\Delta b=\frac{b_{1}-b_{0}}{b_{0}} \times 100 \% \\
\Delta \delta=\frac{\delta_{1}-\delta_{0}}{\delta_{0}} \times 100 \%
\end{gathered}
$$

where: $l_{0}, b_{0}, \delta_{0}, l_{1}, b_{1}, \delta_{1}$ : dimensions of samples before and after thermostating, respectively $(\mathrm{mm})$.

Thermal conductivity of foams was determined by measuring the thermal conductivity coefficient $(\lambda)$ with IZOMET 2104 (Bratislava, Slovakia) according to the norm [39]. The compressive strength was determined using the testing machine with an electronic head FT 100 (Heckert, Chemnitz, Germany) according to the norm [40]. The maximum force and relative strain (decreasing of the height of foam in relation to the initial height, in accordance with the direction of foam rise) or maximum force inducing $10 \%$ relative strain foams before and after exposition at $150{ }^{\circ} \mathrm{C}$ were determined. Horizontal burning test was determined according to the norm [41]. The samples $(150 \mathrm{~mm} \times 50 \mathrm{~mm} \times 13 \mathrm{~mm})$ were weighed and located on stainless steel net $(200 \mathrm{~mm} \times 80 \mathrm{~mm})$. The line on every sample at the distance of $25 \mathrm{~mm}$ from the edge was marked. The sample was set on fire from the bottom using a Bunsen burner with the blue flame of $38 \mathrm{~mm}$ height for $60 \mathrm{~s}$. Then the burner was removed and time of free burning of foam by stopwatch was measured from when the flame or glowing combustion front passed the $25 \mathrm{~mm}$ gauge mark. After the test, the samples were weighed again. The rate of burning $(v)$ was calculated from the Equation (8):

$$
v=\frac{L_{e}}{t_{b}}
$$

where: $L_{e}$ : the distance burnt (between the $25 \mathrm{~mm}$ gauge mark and the point where the flame or glowing combustion front stopped, $\mathrm{mm}$ ), $t_{b}$ : burning time (s).

The mass loss $(\Delta m)$ after burning was calculated according to the Equation (9):

$$
\Delta m=\frac{m_{0}-m}{m_{0}} \times 100 \%
$$

where: $m_{0}, m$ : mass of the sample before and after burning, respectively $(\mathrm{g})$.

Oxygen index was measured with Concept Equipment apparatus (Concept Equipment, Rustington, UK) according to the norm [42]. In the mixture of oxygen and nitrogen, the percentage-limited concentration of oxygen, sufficient to sustain the burning of the sample, was determined. Oxygen index (LOI) was calculated from Equation (10):

$$
L O I=\frac{\left[\mathrm{O}_{2}\right]}{\left[\mathrm{O}_{2}\right]+\left[\mathrm{N}_{2}\right]} \times 100 \%
$$

where: $\left[\mathrm{O}_{2}\right],\left[\mathrm{N}_{2}\right]$ : volumetric flow of oxygen and nitrogen at the limit concentration, respectively $\left(\mathrm{m}^{3} / \mathrm{h}\right)$. 


\section{Results and Discussion}

\subsection{Oligoetherols Synthesis and Properties}

Oligoetherols with 1,3-pyrimidinering were obtained in two ways. In the first method, reaction of BHEU with BA was carried out (Scheme 2).<smiles>O=c1ccn(CCO)c(=O)n1CCOP(O)O</smiles>

Scheme 2. Reaction of 1 mol BHEU with 2 moles BA.

The next obtained product (DOPDEDHB, IV) was treated with excess of EC in the presence of potassium carbonate (Scheme 3).<smiles>O=c1ccn(CCCOB(O)O)c(=O)n1CCOB(O)O</smiles><smiles>O=C1OCCO1</smiles>

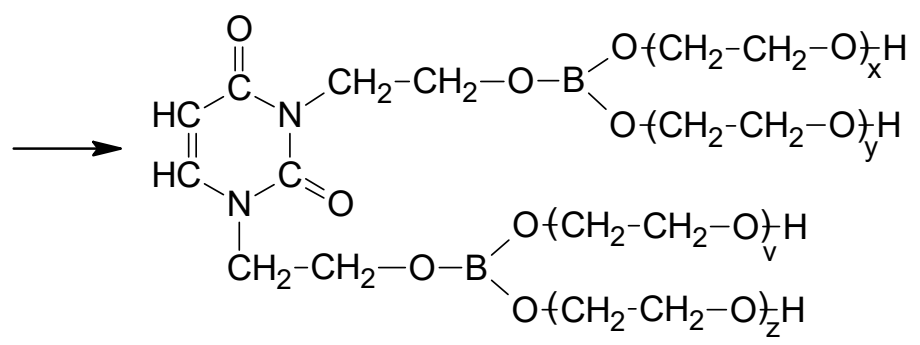

Scheme 3. Reaction of DOPDEDHB with an excess of EC, where: $n=x+y+z=12$ or 16 .

The syntheses were carried out at $160^{\circ} \mathrm{C}$, with a molar ratio of DOPDEDHB to EC equal to 1:12 and 1:16. The amount of EC was selected to obtain an oligoetherol with a high boron content and with a consistency that allows mixing it with the isocyanate (if a smaller amount of EC was added, oligoetherols of large density at room temperature were obtained). The course of the reaction and its end were determined by analyzing the IR spectrum of reactions mixture-the disappearance of the band at $1800 \mathrm{~cm}^{-1}$ of valence vibrations of carbonyl group $\mathrm{C}=\mathrm{O}$ of unreacted $\mathrm{EC}$ was used as the indicator. Dark brown, thick, resin-like, soluble-in-water products were obtained. The structure of the obtained oligoetherols was determined by instrumental methods (IR, ${ }^{1} \mathrm{H}-\mathrm{NMR}$ and MALDI-ToF spectra).

In the IR spectra of the products of the reaction of DOPDEDHB with excess EC (Figure 1) the following were present: a valence vibration band of hydroxyl groups at $3427 \mathrm{~cm}^{-1}$; the asymmetric and symmetric valence vibration bands and the deformation vibration bands of methylene groups at 2931, 2870, and $1454 \mathrm{~cm}^{-1}$, respectively; valence vibration bands of carbonyl groups and of unsaturated bond in the 1,3-pyrimidine ring at 1703 and $1656 \mathrm{~cm}^{-1}$, respectively; valence vibration bands of the B-O bond at 1411 and 
$1326 \mathrm{~cm}^{-1}$; valence vibrations of ether groups $(\mathrm{C}-\mathrm{O}-\mathrm{C})$ at $1118 \mathrm{~cm}^{-1}$; and $\mathrm{C}-\mathrm{O}$ bonds in primary alcohols at $1060 \mathrm{~cm}^{-1}$. The bands at 928,766 , and $549 \mathrm{~cm}^{-1}$ were attributed to vibration of the 1,3-pyrimidine ring. In the IR spectra of oligoetherols, there was also a band at $1746 \mathrm{~cm}^{-1}$, derived from the valence vibrations of the ester groups $\left(-\mathrm{CH}_{2}-\mathrm{O}-\mathrm{CO}-\right.$ $\mathrm{O})$. This indicates that the reaction took place to a small extent with preservation of the carbonate group.

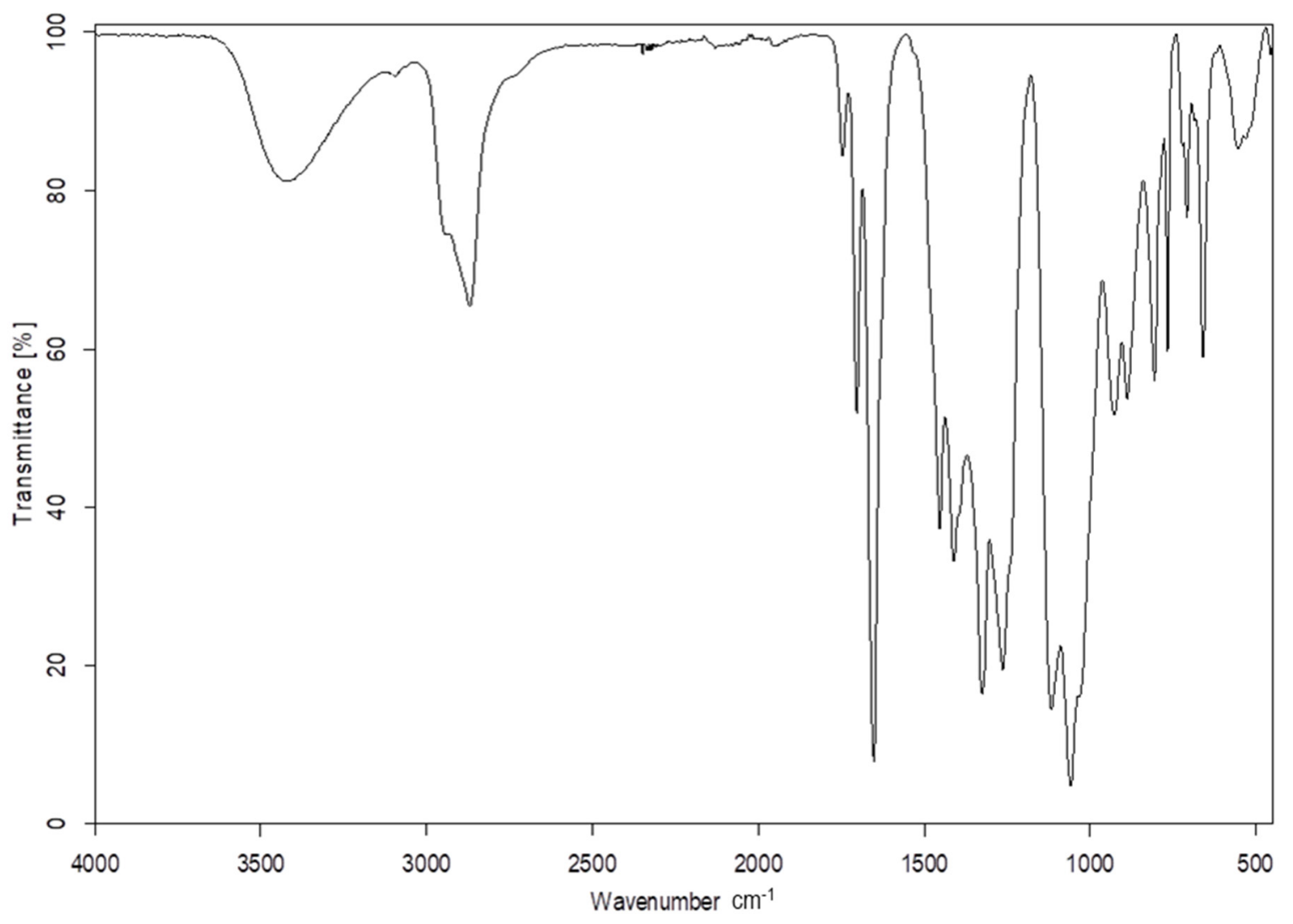

Figure 1. IR spectrum of the product of reaction of 1 mol DOPDEDHB with 12 moles EC.

In the ${ }^{1} \mathrm{H}-\mathrm{NMR}$ spectra of the obtained oligoetherols (Figure 2), signals of methylene protons in oxyethylene groups $\left(-\mathrm{O}-\mathrm{CH}_{2}-\mathrm{CH}_{2}-\mathrm{O}-\right)$ and borate groups $\left(-\mathrm{CH}_{2}-\mathrm{O}-\mathrm{B}\right)$ at a chemical shift in the range of 3.4-3.7 ppm and the ester groups $\left(-\mathrm{CH}_{2}-\mathrm{O}-\mathrm{CO}-\mathrm{O}\right)$ at $4.18 \mathrm{ppm}$ were observed. The intensity of these signals increased as the amount of EC used in the reaction increased. The signals of protons connected with unsaturated carbon atoms in the ring $=\mathrm{C}(5)-\mathrm{H}$ and $=\mathrm{C}(6)-\mathrm{H}$ were located at a chemical shift of 5.64 and $7.58 \mathrm{ppm}$, respectively. The splitting of the signal of the proton of carbon $\mathrm{C}(6)$ in the ring was associated with various atomic surrounding of the proton. Signals of hydroxyl protons appeared in the range of 3.7-5 ppm and overlapped with the signals of methylene protons, connected with nitrogen atoms ( $\left.>\mathrm{N}-\mathrm{CH}_{2}-\mathrm{CH}_{2}-\mathrm{O}-, 3.7-4 \mathrm{ppm}\right)$, which was confirmed by the spectra with $\mathrm{D}_{2} \mathrm{O}$ (Figure 2a,b). Since, after $\mathrm{D}_{2} \mathrm{O}$ addition, the signal at $4.75 \mathrm{ppm}$ had not disappeared completely, it can be concluded that unsaturated bonds were present in the reactions products. Unsaturated bonds formed at the ends of chains as a result of $\mathrm{H}_{2} \mathrm{O}$ elimination in the high-temperature process $\left(160^{\circ} \mathrm{C}\right)$. Their amount was not significant. In the spectra a characteristic signal at $3.57 \mathrm{ppm}$ was also visible, indicating the presence of 1,4-dioxane in the product. This compound was formed at high temperature from ethylene glycol. Ethylene glycol was formed in the side reaction of EC with water contained in the hydroborate. 
a)

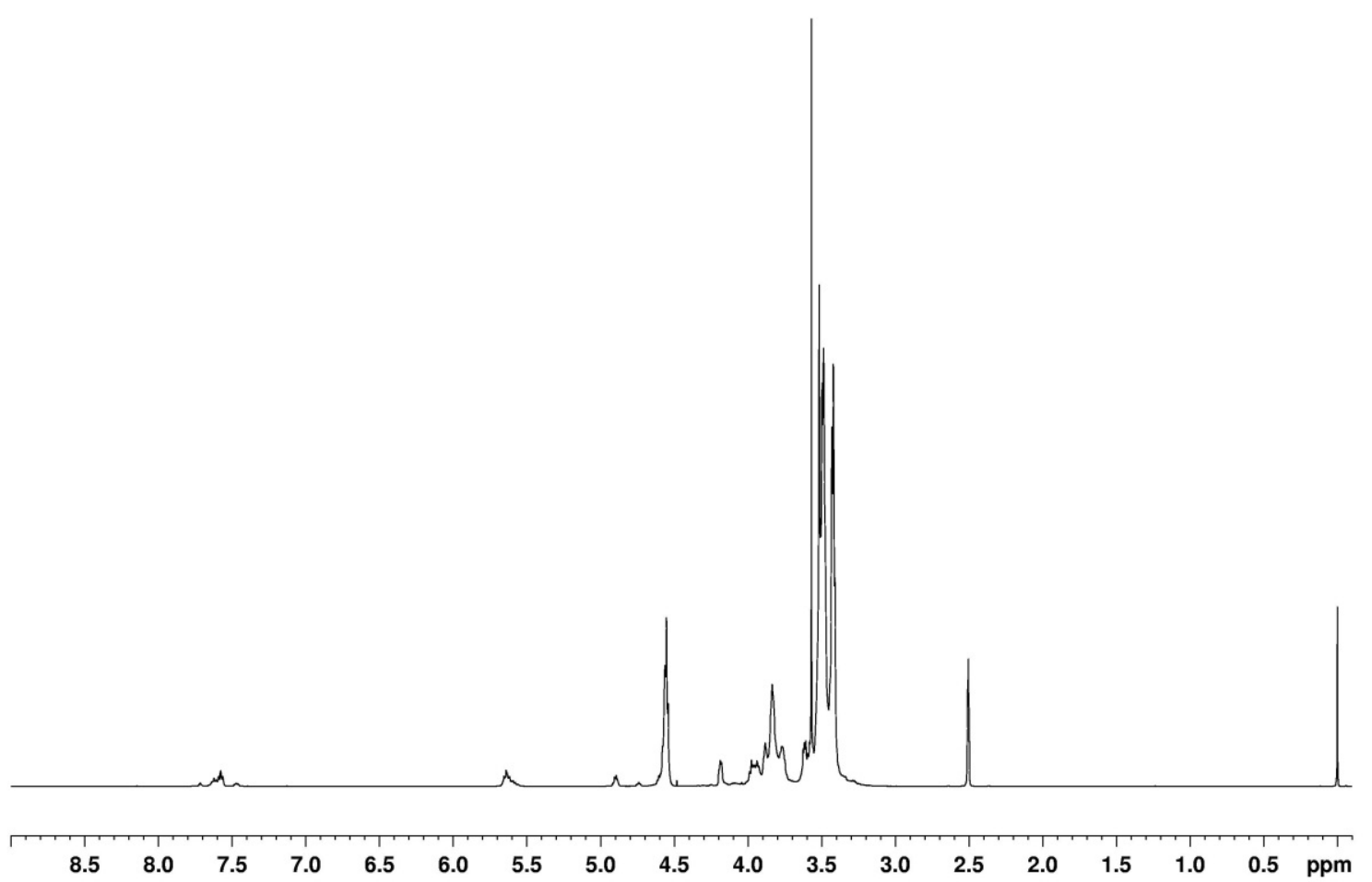

b)

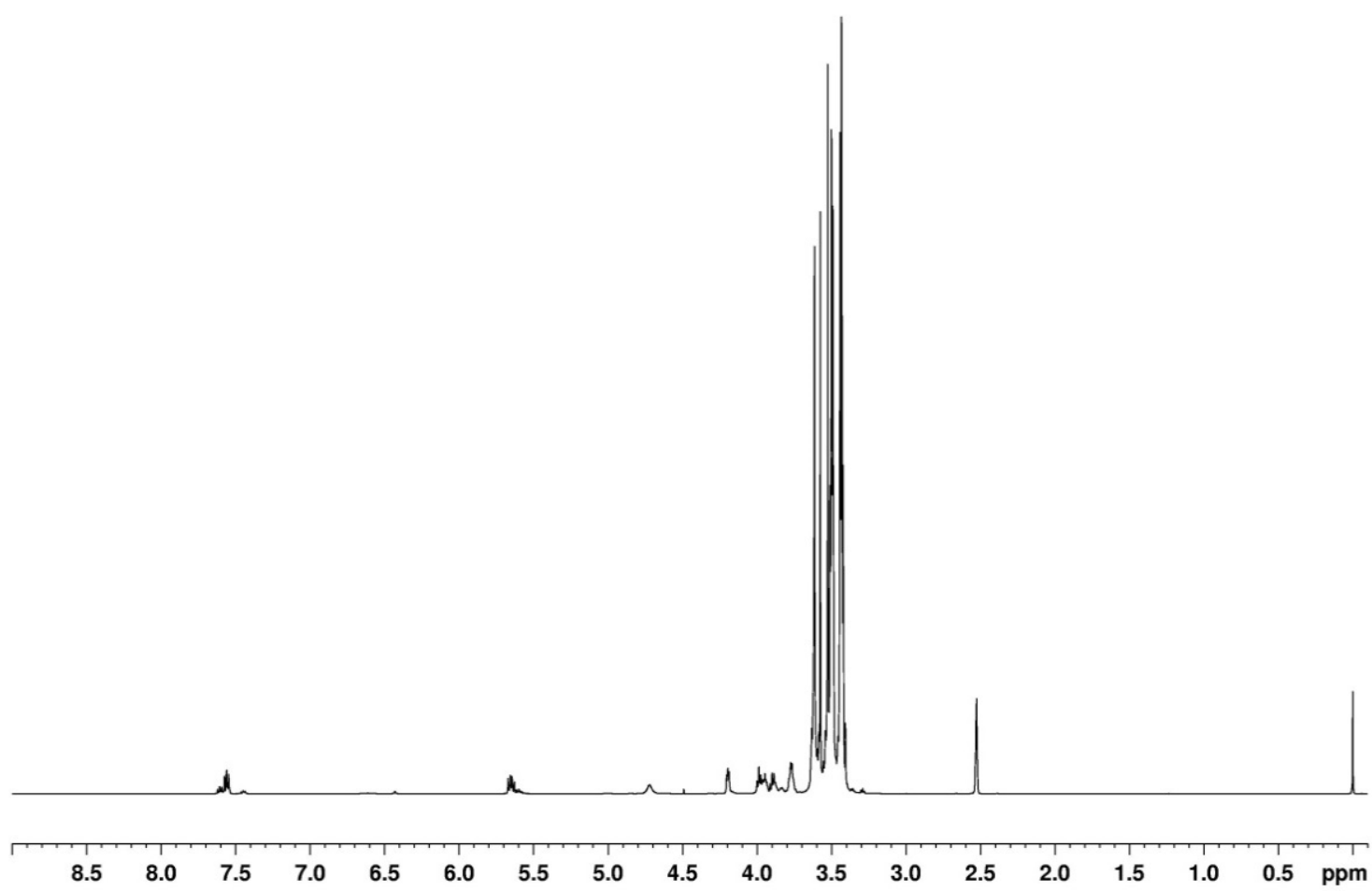

Figure 2. ${ }^{1} \mathrm{H}-\mathrm{NMR}$ spectrum of the product of reaction of 1 mol DOPDEDHB with 12 moles EC (a), with $\mathrm{D}_{2} \mathrm{O}(\mathbf{b})$.

Therefore, a chromatographic analysis was performed to identify and evaluate the content of by-products of ethylene glycol and the products of its consecutive reactions with EC. An analysis of postreaction mixtures indicated presence of ethylene glycol and tetraethylene glycol in amounts: $1.28 \%$ and $5.78 \%$ in the product of reaction of DOPDEDHB with 12 moles EC, and $0.89 \%$ and $7.49 \%$ in product of reaction of DOPDEDHB with 16 moles EC, respectively. Analysis of the MALDI-ToF spectra of products of reactions of 
DOPDEDHB with EC indicated the formation of oligoetherols with different oxyethylene chain lengths (Table 2). In spectra, the peaks of molecular ions differing by $\mathrm{M} / \mathrm{z}=44.05$ (oxyethylene sub-units) could be observed. Since the analysis of the IR and ${ }^{1} \mathrm{H}-\mathrm{NMR}$ spectra of the oligoetherols indicated presence of ester groups, structures containing a carbonate groups were also proposed (the molar mass of oxyethylene and carbonate groups is the same). The spectra showed that unsaturated structures formed. Many of the unsaturated structures were generated in the conditions of registration of the MALDI-ToF spectrum (high temperature favors the elimination of water from the hydroxyethyl groups). Analysis of the ${ }^{1} \mathrm{H}-\mathrm{NMR}$ spectra with $\mathrm{D}_{2} \mathrm{O}$ showed that a very small amount of unsaturated structures were present. The occurrence of molecular peaks with mass increased by the unit $\mathrm{M} / \mathrm{z}=39$, was related to the presence of potassium cations from the catalyst used (potassium carbonate). The spectrum also confirmed the formation of 1,4-dioxane and glycols (Table 2, No. 1-3).

Table 2. Interpretation of MALDI-ToF spectrum of the product of reaction of 1 mol DOPDEDHB with 12 moles EC.

\begin{tabular}{|c|c|c|c|}
\hline No & Signal Position (M/z) & Probable Structure of Molecular Ion & Calc. Molecular Weight (g/mol) \\
\hline 1 & 83.1 & Ethylene glycol $+\mathrm{K}^{+}-\mathrm{H}_{2} \mathrm{O}$ & 83.0 \\
\hline 2 & 89.1 & 1,4-dioxane $+\mathrm{H}^{+}$ & 89.1 \\
\hline 3 & 233.1 & Tetraethylene glycol $+\mathrm{K}^{+}$ & 233.1 \\
\hline \multirow{2}{*}{4} & \multirow{2}{*}{397.3} & DOPDEDHB $+2 \mathrm{OE}-\mathrm{H}_{2} \mathrm{O}+\mathrm{K}^{+}$ & 397.1 \\
\hline & & $\mathrm{DOPDEDHB}+\mathrm{OE}-\mathrm{H}_{2} \mathrm{O}+\mathrm{CO}_{2}+\mathrm{K}^{+}$ & 397.1 \\
\hline 5 & 415.1 & $\mathrm{DOPDEDHB}+2 \mathrm{OE}+\mathrm{K}^{+}$ & 415.1 \\
\hline \multirow{2}{*}{6} & \multirow{2}{*}{421.1} & DOPDEDHB $+3 \mathrm{OE}+\mathrm{H}^{+}$ & 421.1 \\
\hline & & $\mathrm{DOPDEDHB}+2 \mathrm{OE}+\mathrm{CO}_{2}+\mathrm{H}^{+}$ & 421.1 \\
\hline \multirow{2}{*}{7} & \multirow{2}{*}{459.2} & DOPDEDHB + $3 \mathrm{OE}+\mathrm{K}^{+}$ & 459.1 \\
\hline & & $\mathrm{DOPDEDHB}+2 \mathrm{OE}+\mathrm{CO}_{2}+\mathrm{K}^{+}$ & 459.1 \\
\hline \multirow{2}{*}{8} & \multirow{2}{*}{465.2} & DOPDEDHB $+4 \mathrm{OE}+\mathrm{H}^{+}$ & 465.2 \\
\hline & & $\mathrm{DOPDEDHB}+3 \mathrm{OE}+\mathrm{CO}_{2}+\mathrm{H}^{+}$ & 465.2 \\
\hline \multirow{2}{*}{9} & \multirow{2}{*}{503.2} & DOPDEDHB $+4 \mathrm{OE}+\mathrm{K}^{+}$ & 503.2 \\
\hline & & $\mathrm{DOPDEDHB}+3 \mathrm{OE}+\mathrm{CO}_{2}+\mathrm{K}^{+}$ & 503.2 \\
\hline \multirow{2}{*}{10} & \multirow{2}{*}{509.2} & DOPDEDHB $+5 \mathrm{OE}+\mathrm{H}^{+}$ & 509.2 \\
\hline & & $\mathrm{DOPDEDHB}+4 \mathrm{OE}+\mathrm{CO}_{2}+\mathrm{H}^{+}$ & 509.2 \\
\hline \multirow{2}{*}{11} & \multirow{2}{*}{534.3} & DOPDEDHB +6 OE $-\mathrm{H}_{2} \mathrm{O}$ & 534.2 \\
\hline & & $\mathrm{DOPDEDHB}+5 \mathrm{OE}-\mathrm{H}_{2} \mathrm{O}+\mathrm{CO}_{2}$ & 534.2 \\
\hline \multirow{2}{*}{12} & \multirow{2}{*}{553.3} & $\mathrm{DOPDEDHB}+6 \mathrm{OE}+\mathrm{H}^{+}$ & 553.3 \\
\hline & & $\mathrm{DOPDEDHB}+5 \mathrm{OE}+\mathrm{CO}_{2}+\mathrm{H}^{+}$ & 553.3 \\
\hline \multirow{2}{*}{13} & \multirow{2}{*}{579.4} & $\mathrm{DOPDEDHB}+7 \mathrm{OE}-\mathrm{H}_{2} \mathrm{O}+\mathrm{H}^{+}$ & 579.3 \\
\hline & & $\mathrm{DOPDEDHB}+6 \mathrm{OE}-\mathrm{H}_{2} \mathrm{O}+\mathrm{CO}_{2}+\mathrm{H}^{+}$ & 579.3 \\
\hline \multirow{2}{*}{14} & \multirow{2}{*}{597.3} & DOPDEDHB $+7 \mathrm{OE}+\mathrm{H}^{+}$ & 597.3 \\
\hline & & $\mathrm{DOPDEDHB}+6 \mathrm{OE}+\mathrm{CO}_{2}+\mathrm{H}^{+}$ & 597.3 \\
\hline \multirow{2}{*}{15} & \multirow{2}{*}{641.2} & DOPDEDHB $+8 \mathrm{OE}+\mathrm{H}^{+}$ & 641.3 \\
\hline & & $\mathrm{DOPDEDHB}+7 \mathrm{OE}+\mathrm{CO}_{2}+\mathrm{H}^{+}$ & 641.3 \\
\hline \multirow{2}{*}{16} & \multirow{2}{*}{773.5} & DOPDEDHB + $11 \mathrm{OE}+\mathrm{H}^{+}$ & 773.4 \\
\hline & & $\mathrm{DOPDEDHB}+10 \mathrm{OE}+\mathrm{CO}_{2}+\mathrm{H}^{+}$ & 773.4 \\
\hline
\end{tabular}

where: DOPDEDHB is a fragmentation product of 2,4-dioxopyrimidine-1,3-diethyl bis(dihydroborate), $\mathrm{OE}$ is an oxyethylene group, $\mathrm{CO}_{2}$ is a carbonate group, and the number preceding the symbol indicates the number of oxyethylene groups in a structure.

The second method of synthesis of oligoetherols relied on the direct reaction of BHEU with BA and EC (Scheme 4).

The syntheses were carried out at an initial molar ratio BHEU, BA, and EC equal to 1:2:12 and 1:3:12. The mixture was heated at $120^{\circ} \mathrm{C}$ for $4 \mathrm{~h}$. This temperature allowed the start of the esterification of BHEU with BA and the reaction of BA with EC [31]. After this time, potassium carbonate (catalyst) was added and the temperature was increased to $160{ }^{\circ} \mathrm{C}$. This temperature allowed the start of the reaction of EC with hydroxyethyl and hydroborate groups. The end of the reaction, as before, was determined by analyzing the IR spectrum of the reactions mixture. Dark brown, liquid, resin-like, soluble in water products were obtained. The structure of the obtained oligoetherols was determined by instrumental 
methods (IR, ${ }^{1} \mathrm{H}-\mathrm{NMR}$ and MALDI-ToF spectra). The IR spectra of the reaction products of BHEU with BA and EC (Figure 3) and the reaction products of DOPDEDHB with EC (Figure 1) were similar. In the spectra of the reactions products of BHEU with BA and EC (Figure 3), the presence of the band from the valence vibrations of the ester groups at $1746 \mathrm{~cm}^{-1}$ was not found only.

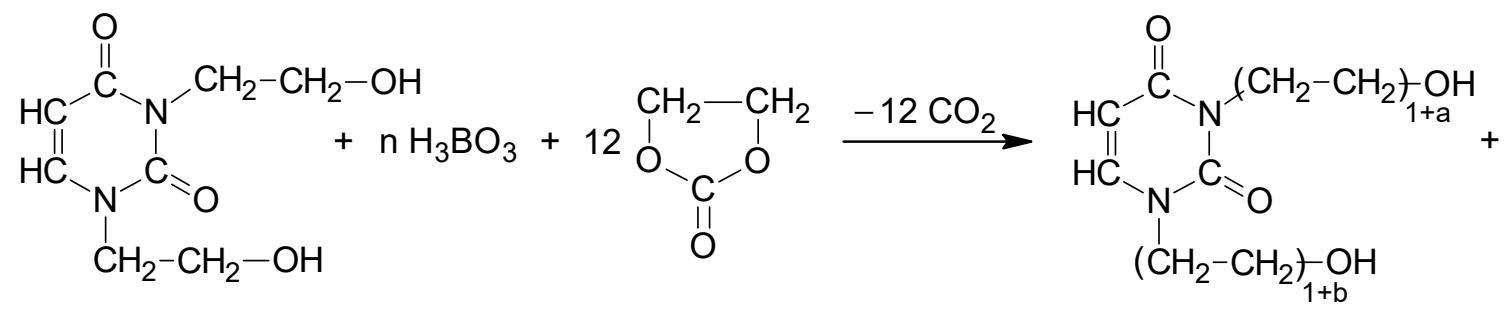

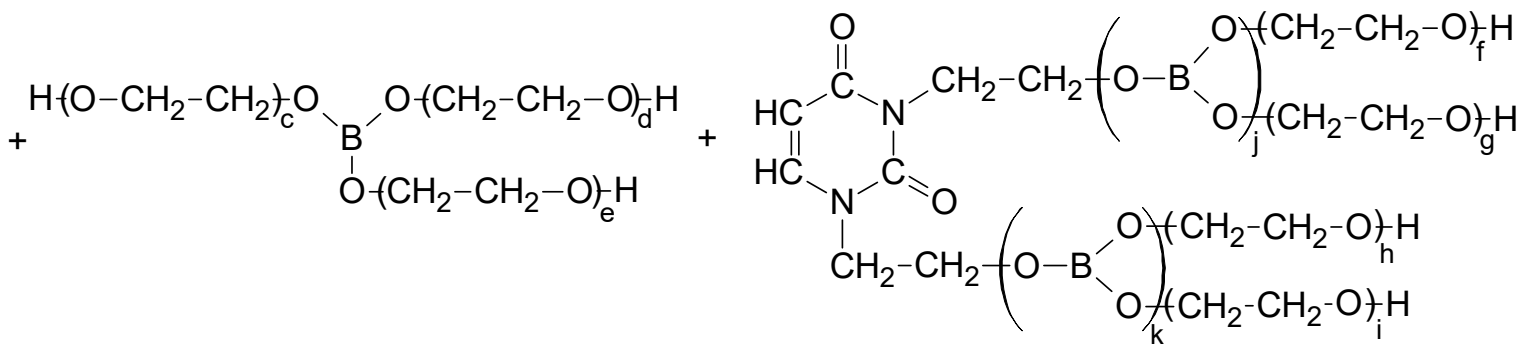

Scheme 4. Reaction of BHEU with BA and EC, where: $n=2$ or $3, a+b+c+d+e+f+g+h+i=12, j+k<2$ or 3 .

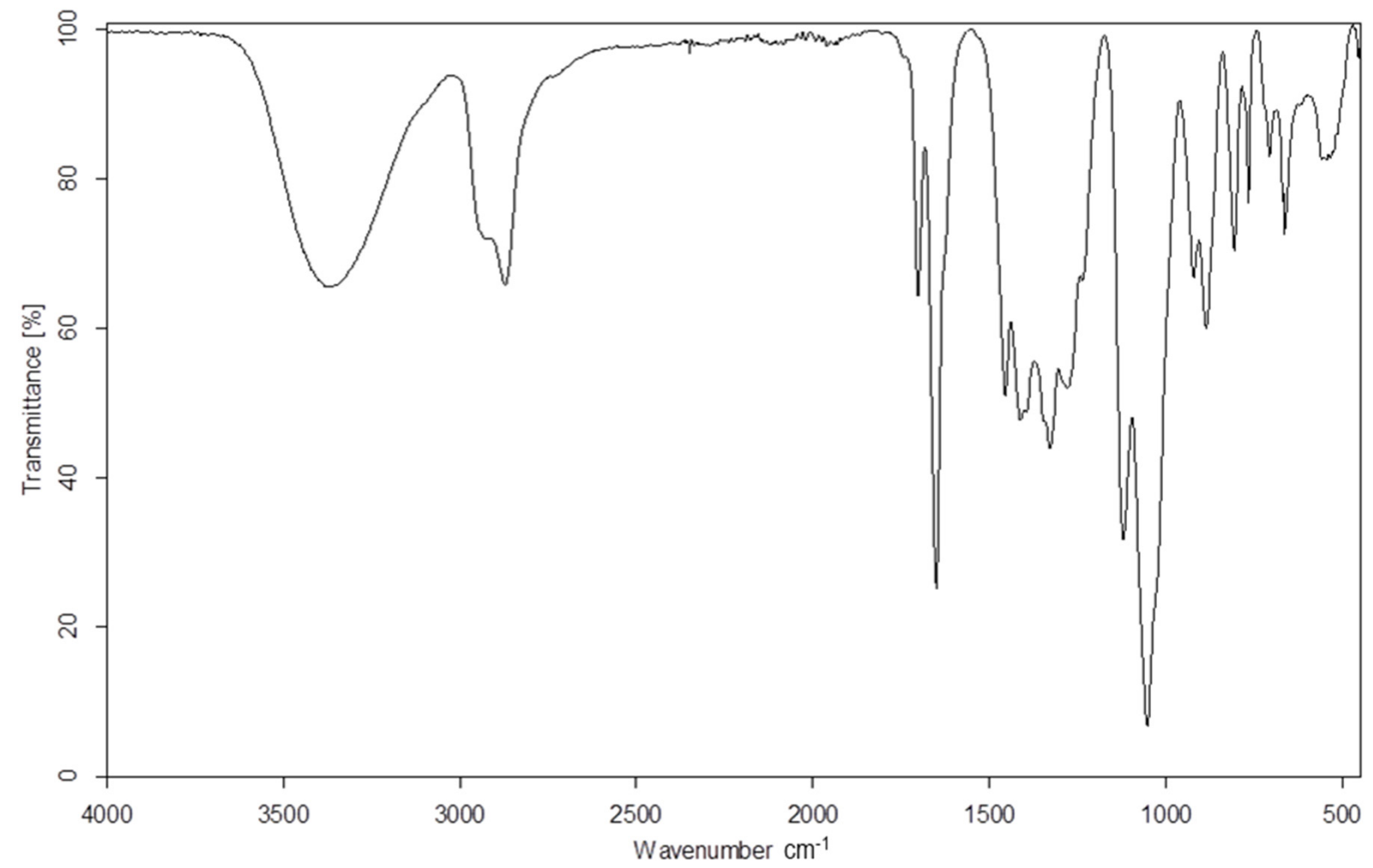

Figure 3. IR spectrum of the product of reaction of 1 mol BHEU with 2 moles BA and 12 moles EC.

Also, the ${ }^{1} \mathrm{H}-\mathrm{NMR}$ spectra of the reaction products of BHEU with BA and EC (Figures 4 and 5) were similar to the spectra of the products obtained in the reaction of DOPDEDHB with EC (Figure 2a). In the spectra, however, signals of methylene protons 
in ester groups were not observed. The use of 3 moles of BA in the reaction resulted in the presence in the spectrum (Figure 5) of small signals of protons of hydroborate groups $(7.12 \mathrm{ppm})$ and of unreacted BA (8.14 ppm).

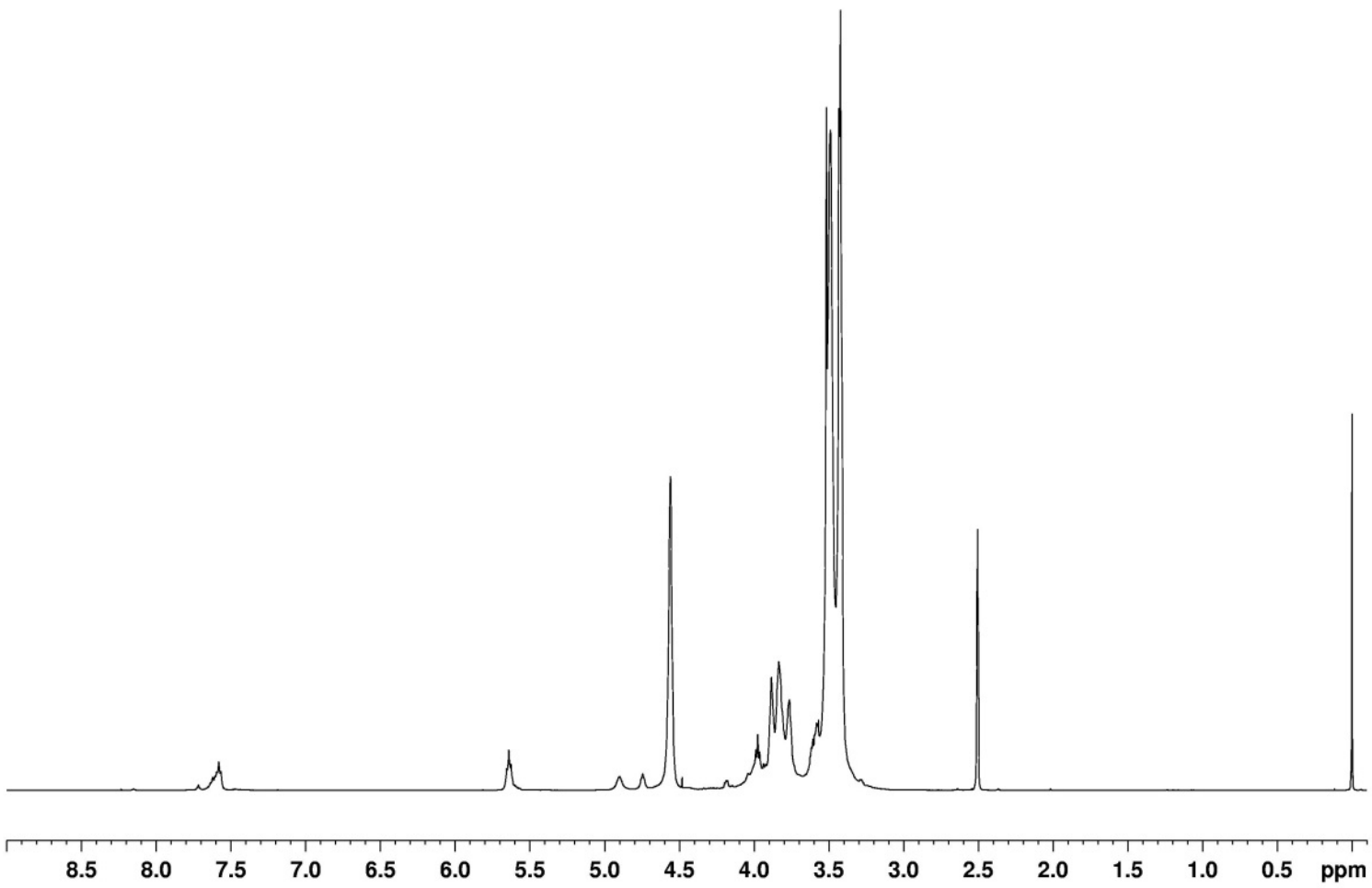

Figure $4 .{ }^{1} \mathrm{H}-\mathrm{NMR}$ spectrum of the product of reaction of 1 mol BHEU with 2 moles BA and 12 moles EC.

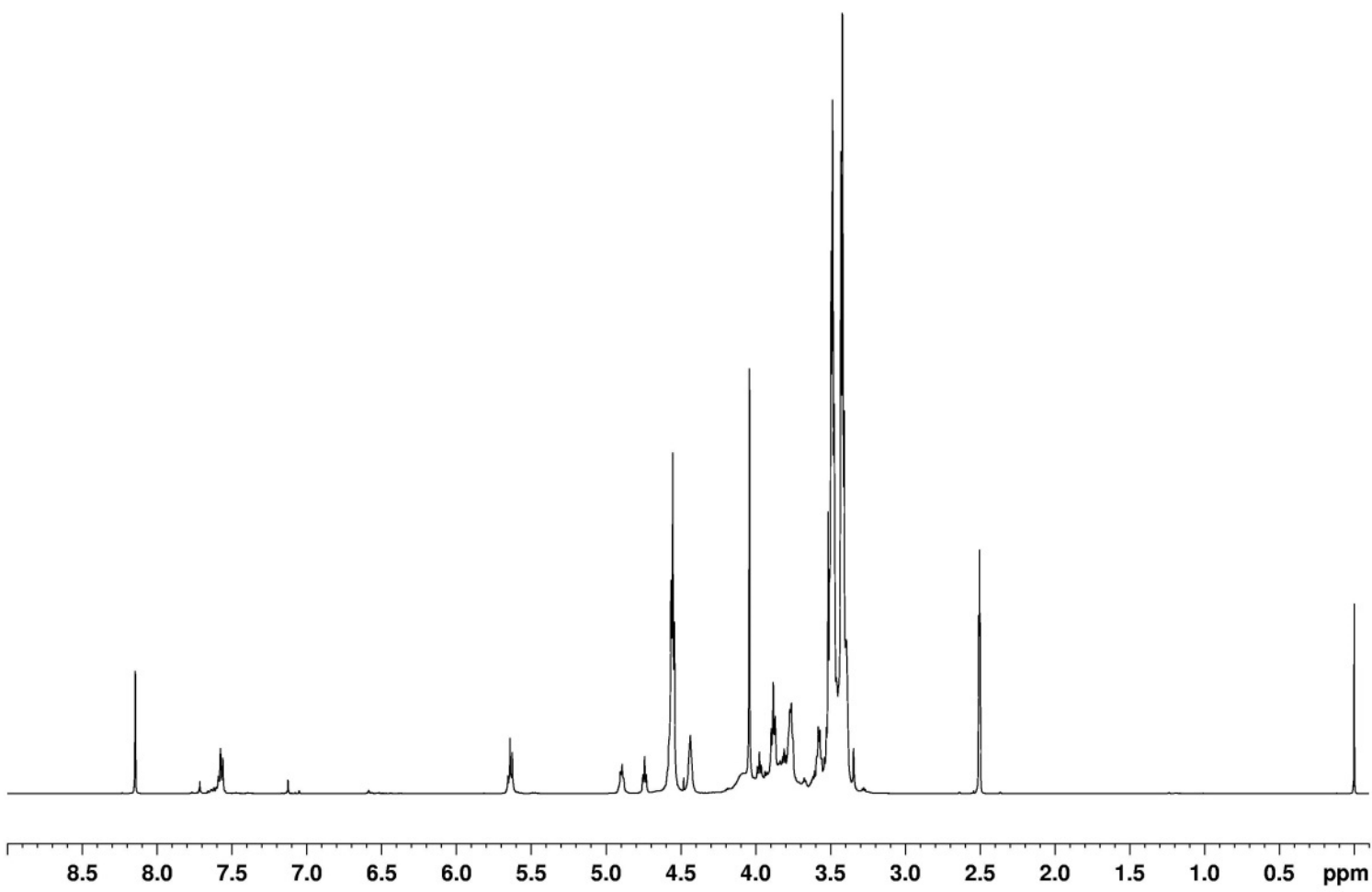

Figure 5. ${ }^{1} \mathrm{H}-\mathrm{NMR}$ spectrum of the product of reaction of 1 mol BHEU with 3 moles BA and 12 moles EC. 
Chromatographic analysis of postreaction mixtures indicated presence $3.03 \%$ of ethylene glycol and $2.89 \%$ of tetraethylene glycol in product of reaction of BHEU with 2 moles BA and 12 moles EC and $4.22 \%$ of triethylene glycol in product of reaction of BHEU with 3 moles BA and 12 moles EC. The MALDI-ToF spectra of oligoetherols (Table 3) confirmed the occurrence of the reactions presented in Scheme 4 . The peaks corresponding to the products of reaction of BA with EC (Table 3, Nos. 3, 4, 6, 7, 9, 10, 12-15), BHEU with EC (Table 3, Nos. 5, 8, 10,11, 13, 15-21), 1-(2-hydroxyethyl)-2,4-dioxopyrimidine-3-ethyl dihydroborate/3-(2-hydroxyethyl)-2,4-dioxopyrimidine-1-ethyl dihydroborate (HEDOPEDHB), and DOPDEDHB with EC (Table 3, Nos. 11, 13, 15-21) were present. There were also unsaturated structures in the spectra, with the mass reduced by the unit $\mathrm{M} / \mathrm{z}=18$.

Table 3. Interpretation of MALDI-ToF spectrum of the product of reaction of 1 mol BHEU with 2 moles BA and 12 moles EC.

\begin{tabular}{|c|c|c|c|}
\hline No & Signal Position (M/z) & Probable Structure of Molecular Ion & Calc. Molecular Weight (g/mol) \\
\hline 1 & 83.1 & Ethylene glycol $+\mathrm{K}^{+}-\mathrm{H}_{2} \mathrm{O}$ & 83.0 \\
\hline 2 & 89.1 & 1,4-dioxane $+\mathrm{H}^{+}$ & 89.1 \\
\hline 3 & 145.0 & $\mathrm{BA}+\mathrm{OE}+\mathrm{K}^{+}$ & 145.0 \\
\hline 4 & 189.1 & $\mathrm{BA}+2 \mathrm{OE}+\mathrm{K}^{+}$ & 189.0 \\
\hline 5 & 227.1 & $\mathrm{BHEU}+\mathrm{OE}-\mathrm{H}_{2} \mathrm{O}+\mathrm{H}^{+}$ & 227.1 \\
\hline \multirow{2}{*}{6} & \multirow{2}{*}{233.1} & $\mathrm{BA}+3 \mathrm{OE}+\mathrm{K}^{+}$ & 233.1 \\
\hline & & Tetraethylene glycol $+\mathrm{K}^{+}$ & 233.1 \\
\hline 7 & 239.1 & $\mathrm{BA}+4 \mathrm{OE}+\mathrm{H}^{+}$ & 239.1 \\
\hline \multirow{2}{*}{8} & \multirow{2}{*}{245.1} & HEDOPEDHB + $\mathrm{H}^{+}$ & 245.1 \\
\hline & & $\mathrm{BHEU}+\mathrm{OE}+\mathrm{H}^{+}$ & 245.1 \\
\hline \multirow{2}{*}{9} & \multirow{2}{*}{277.1} & $\mathrm{BA}+3 \mathrm{OE}-\mathrm{H}_{2} \mathrm{O}+\mathrm{H}^{+}$ & 277.1 \\
\hline & & $\mathrm{BA}+4 \mathrm{OE}+\mathrm{K}^{+}$ & 277.1 \\
\hline \multirow{3}{*}{10} & \multirow{3}{*}{283.2} & $\mathrm{BHEU}+\mathrm{OE}+\mathrm{K}^{+}$ & 283.1 \\
\hline & & $\mathrm{BA}+5 \mathrm{OE}+\mathrm{H}^{+}$ & 283.2 \\
\hline & & DOPDEDHB $+\mathrm{H}^{+}$ & 289.1 \\
\hline \multirow[t]{2}{*}{11} & \multirow[t]{2}{*}{289.2} & HEDOPEDHB + OE + $\mathrm{H}^{+}$ & 289.1 \\
\hline & & $\mathrm{BHEU}+2 \mathrm{OE}+\mathrm{H}^{+}$ & 289.1 \\
\hline \multirow[t]{2}{*}{12} & \multirow[t]{2}{*}{321.2} & $\mathrm{BA}+5 \mathrm{OE}+\mathrm{K}^{+}$ & 321.1 \\
\hline & & DOPDEDHB $+\mathrm{K}^{+}$ & 327.1 \\
\hline \multirow{3}{*}{13} & \multirow{3}{*}{327.2} & HEDOPEDHB + OE + $\mathrm{K}^{+}$ & 327.1 \\
\hline & & $\mathrm{BA}+6 \mathrm{OE}+\mathrm{H}^{+}$ & 327.2 \\
\hline & & $\mathrm{BHEU}+2 \mathrm{OE}+\mathrm{K}^{+}$ & 327.2 \\
\hline \multirow[t]{2}{*}{14} & \multirow[t]{2}{*}{365.1} & $\mathrm{BA}+6 \mathrm{OE}+\mathrm{K}^{+}$ & 365.1 \\
\hline & & DOPDEDHB + OE + $\mathrm{K}^{+}$ & 371.1 \\
\hline \multirow{3}{*}{15} & \multirow{3}{*}{371.2} & HEDOPEDHB + 2 OE + $\mathrm{K}^{+}$ & 371.1 \\
\hline & & $\mathrm{BA}+7 \mathrm{OE}+\mathrm{H}^{+}$ & 371.2 \\
\hline & & $\mathrm{BHEU}+3 \mathrm{OE}+\mathrm{K}^{+}$ & 371.2 \\
\hline \multirow{3}{*}{16} & \multirow{3}{*}{376.3} & DOPDEDHB + 2 OE & 376.0 \\
\hline & & $\mathrm{BHEU}+4 \mathrm{OE}$ & 376.3 \\
\hline & & DOPDEDHB + 2 OE + $\mathrm{K}^{+}$ & 415.1 \\
\hline \multirow[t]{3}{*}{17} & \multirow[t]{3}{*}{415.1} & HEDOPEDHB + $3 \mathrm{OE}+\mathrm{K}^{+}$ & 415.1 \\
\hline & & $\mathrm{BHEU}+4 \mathrm{OE}+\mathrm{K}^{+}$ & 415.1 \\
\hline & & DOPDEDHB + $3 \mathrm{OE}+\mathrm{H}^{+}$ & 421.1 \\
\hline \multirow[t]{3}{*}{18} & \multirow[t]{3}{*}{421.2} & HEDOPEDHB + $4 \mathrm{OE}+\mathrm{H}^{+}$ & 421.2 \\
\hline & & $\mathrm{BHEU}+5 \mathrm{OE}+\mathrm{H}^{+}$ & 421.2 \\
\hline & & $\mathrm{DOPDEDHB}+4 \mathrm{OE}+\mathrm{H}^{+}$ & 465.2 \\
\hline \multirow[t]{2}{*}{19} & \multirow[t]{2}{*}{465.2} & HEDOPEDHB $+5 \mathrm{OE}+\mathrm{H}^{+}$ & 465.2 \\
\hline & & $\mathrm{BHEU}+6 \mathrm{OE}+\mathrm{H}^{+}$ & 465.2 \\
\hline & & $\mathrm{DOPDEDHB}+6 \mathrm{OE}+\mathrm{H}^{+}$ & 553.3 \\
\hline 20 & 553.2 & $\mathrm{BHEU}+8 \mathrm{OE}+\mathrm{H}^{+}$ & 553.3 \\
\hline 21 & 7735 & DOPDEDHB $+11 \mathrm{OE}+\mathrm{H}^{+}$ & 773.4 \\
\hline 21 & 773.5 & $\mathrm{BHEU}+13 \mathrm{OE}+\mathrm{H}^{+}$ & 773.4 \\
\hline
\end{tabular}

where: BA, BHEU, HEDOPEDHB, and DOPDEDHB are fragmentation products of boric acid, 1,3-bis(2-hydroxyethyl)uracil, 1-(2-hydroxyethyl)-2,4-dioxopyrimidine-3-ethyl dihydroborate/3-(2-hydroxyethyl)-2,4-dioxopyrimidine-1-ethyl dihydroborate, 2,4dioxopyrimidine-1,3-diethyl bis(dihydroborate); $\mathrm{OE}$ is an oxyethylene group; and the number preceding the symbol indicates the number of oxyethylene groups in a structure. 
The physical properties of oligoetherols were examined. Measured viscosity, density, and surface tension values (Table 4) showed that these obtained compounds are suitable substrates for obtaining polyurethane foams.

Table 4. The physical properties of oligoetherols.

\begin{tabular}{cccc}
\hline Oligoetherol-Product of Reaction & Viscosity $\left(\mathbf{N} \times \mathbf{s} / \mathbf{m}^{\mathbf{2}}\right) \times \mathbf{1 0}^{\mathbf{3}}$ & Density $\left(\mathbf{g} / \mathbf{c m}^{\mathbf{3}}\right)$ & Surface Tension $(\mathbf{N} / \mathbf{m}) \times \mathbf{1 0 ^ { 3 }}$ \\
\hline DOPDEDHB:EC & 79,500 & 1.25 & 51 \\
1:12 & & & 52 \\
DOPDEDHB:EC & 192,600 & 1.24 & 50 \\
1:16 & 10,000 & 1.24 & 49 \\
BHEU:BA:EC & & & \\
1:2:12 & 7600 & 1.25 & \\
BHEU:BA:EC & & & 49 \\
1:3:12 & & & \\
\hline
\end{tabular}

\subsection{Polyurethane Foams Synthesis}

In the next stage, the obtained oligoetherols as polyol components to prepare polyurethane foams were used. Foaming was carried out in a laboratory scale. The composition of foaming samples was selected experimentally. As a catalyst, triethylamine was used, and as a surfactant, silicone L-6900 was applied. It was found that foams with regular, small pores are obtained using $3 \mathrm{wt} \%$ of water, $2.7-3.85 \mathrm{wt} \%$ of catalyst, $1.95 \mathrm{wt} \%$ of surfactant and 140-160 $\mathrm{g}$ of isocyanate per $100 \mathrm{~g}$ of oligoetherol (Table 1). For this composition of the reaction mixture, the creaming time was in the range of 27-46 s, the expanding time was 9-17 s, and the foams immediately dried (Table 1).

Based on digital images of foams (Figure 6) one can notice that foams obtained from oligoetherols synthesized by the two-step method did not differ much from foams based on oligoetherols obtained in the direct reaction of BHEU with BA and EC. Digital images of compositions no. 2 and 9 (Figure 6) showed that the pore diameter was between 300 and $600 \mu \mathrm{m}$.

\subsection{Properties of Foams}

The physical properties-apparent density, water uptake, dimension stability, compression strength, thermal conductivity coefficient, thermal resistance, and flammabilityof selected polyurethane foams were studied.

The apparent densities of the foams were in the range of $56-91 \mathrm{~kg} / \mathrm{m}^{3}$ (Table 5), so they were classified as rigid materials. Along with the increase in the content of boron in foams, their apparent densities increased. The highest density $\left(91 \mathrm{~kg} / \mathrm{m}^{3}\right)$ showed the foam synthesized from oligoetherol obtained in the direct reaction of BHEU, BA, and EC with the initial molar ratio of the reactants equal to 1:3:12. The obtained foams had a higher apparent density than the foams based on oligoetherols synthetized from 6-aminouracil (AU), EC, and propylene oxide (PO) (Table 5).

Water uptake of the obtained foams (Table 5) was significantly larger than one of the foams without boron incorporated, prepared from oligoetherols synthesized in reactions of AU with EC and PO [20]. Water absorption after $24 \mathrm{~h}$ of exposition was between 8.05-27.62 vol\%, the lowest uptake ( $8.05 \mathrm{vol} \%)$ characterized the foam based on product of reaction of 1 mole of DOPDEDHB with 16 moles EC (Table 5). Increased water absorption of obtained foams was due to the presence of boron and the formation of a coordination bond between the water oxygen atom and the boron atom.

Dimensional stability tests showed that shrinkage of the foams after $40 \mathrm{~h}$ exposure at $150^{\circ} \mathrm{C}$ is small (Table 5). The largest shrink was observed for composition no. 2, and the smallest for composition no. 4 . The foams without boron atoms showed both positive and negative dimensional changes (Table 5). 
Table 5. Density, absorption of water, and linear dimension stability of selected polyurethane foams.

\begin{tabular}{|c|c|c|c|c|c|c|c|c|c|c|}
\hline \multirow{3}{*}{$\begin{array}{l}\text { Composition Number } \\
\text { (From Oligoetherol) }\end{array}$} & \multirow{3}{*}{$\begin{array}{l}\text { Density } \\
\left(\mathrm{kg} / \mathrm{m}^{3}\right)\end{array}$} & \multirow{2}{*}{\multicolumn{3}{|c|}{ Absorption of Water (vol\%) }} & \multicolumn{6}{|c|}{ Linear Dimensions Stability at Temperature $150{ }^{\circ} \mathrm{C}$} \\
\hline & & & & & \multicolumn{2}{|c|}{ Length Increase (\%) } & \multicolumn{2}{|c|}{ Width Increase $(\%)$} & \multicolumn{2}{|c|}{ Thickness Increase (\%) } \\
\hline & & After $5 \mathrm{Mmin}$ & After $3 \mathrm{~h}$ & After $24 \mathrm{~h}$ & After $20 \mathrm{~h}$ & After $40 \mathrm{~h}$ & After $20 \mathrm{~h}$ & After $40 \mathrm{~h}$ & After $20 \mathrm{~h}$ & After $40 \mathrm{~h}$ \\
\hline $\begin{array}{c}2 \\
\text { (BHEU:BA:EC = 1:2:12) }\end{array}$ & 66 & 4.37 & 9.61 & 27.62 & 3.19 & 4.65 & 3.00 & 3.70 & 2.94 & 4.84 \\
\hline $\begin{array}{c}4 \\
\text { (BHEU:BA:EC = 1:3:12) }\end{array}$ & 91 & 4.44 & 11.22 & 18.21 & 0.70 & 0.95 & 0.28 & 0.56 & -0.29 & 0.16 \\
\hline $\begin{array}{c}7 \\
\text { (DOPDEDHB:EC = 1:12) }\end{array}$ & 72 & 3.76 & 7.76 & 18.40 & 2.47 & 3.40 & 1.51 & 2.15 & 4.21 & 5.24 \\
\hline $\begin{array}{c}9 \\
(\text { DOPDEDHB:EC }=1: 16)\end{array}$ & 56 & 2.21 & 5.00 & 8.05 & 0.78 & 2.33 & 0.72 & 2.77 & -1.96 & 1.19 \\
\hline $\mathrm{AU}: \mathrm{EC}=1: 6[19]$ & 32 & 4.45 & 6.4 & 8.7 & 0.17 & 0.34 & -0.61 & -0.31 & 2.23 & 2.68 \\
\hline AU:EC:PO = 1:6:6 [20] & 42 & 2.57 & 4.15 & 5.28 & -0.29 & 2.03 & 2.36 & 4.72 & -1.94 & 0 \\
\hline
\end{tabular}



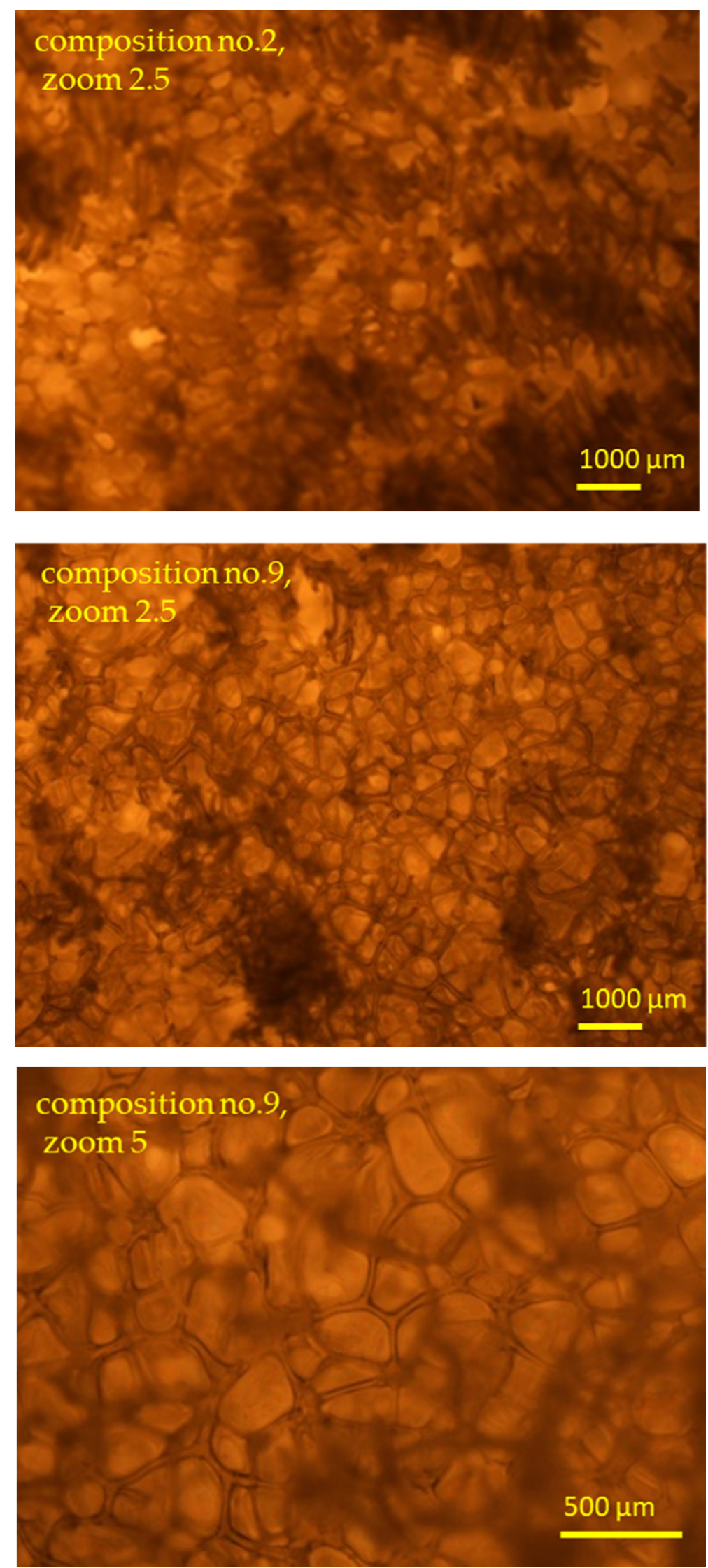

Figure 6. Microscope image of the foams. 
The thermal resistance of foams was determined by registering the loss of mass of compositions at $150^{\circ} \mathrm{C}, 175^{\circ} \mathrm{C}$, and $200^{\circ} \mathrm{C}$ (Table 6). The samples were exposed to thermal treatment for one month, because the foams reach a constant mass during this time. After $4 \mathrm{~h}$ of heating at $200{ }^{\circ} \mathrm{C}$, all compositions showed a significant loss of mass, very high shrinkage, and deformation, therefore the tests at this temperature were not continued. All samples showed distortion of their shape after 30 days of thermal treatment at temperature $175{ }^{\circ} \mathrm{C}$ (Figure 7), and after 30 day of thermal treatment at $150{ }^{\circ} \mathrm{C}$ only sample No. 4 showed distortion.

Table 6. Thermal resistance of selected polyurethane foams.

\begin{tabular}{|c|c|c|c|c|c|c|}
\hline \multirow{2}{*}{$\begin{array}{l}\text { Composition Number } \\
\text { (From Oligoetherol) }\end{array}$} & \multicolumn{3}{|c|}{$\begin{array}{c}\text { The Mass Loss After } 30 \text { Days Heating at } \\
\text { Temperature (wt \%) }\end{array}$} & \multicolumn{3}{|c|}{ Thermal Analysis } \\
\hline & $150^{\circ} \mathrm{C}$ & $175^{\circ} \mathrm{C}$ & $200^{\circ} \mathrm{C}$ & $\mathrm{T}_{10 \%}\left({ }^{\circ} \mathrm{C}\right)$ & $\mathrm{T}_{25 \%}\left({ }^{\circ} \mathrm{C}\right)$ & $\mathrm{T}_{50 \%}\left({ }^{\circ} \mathrm{C}\right)$ \\
\hline $\begin{array}{c}2 \\
\text { (BHEU:BA:EC }=1: 2: 12)\end{array}$ & 19 & 35 & - & 235 & 252 & 303 \\
\hline $\begin{array}{c}4 \\
\text { (BHEU:BA:EC = 1:3:12) }\end{array}$ & 24 & 38 & - & 202 & 242 & 299 \\
\hline $\begin{array}{c}7 \\
(\mathrm{DOPDEDHB}: \mathrm{EC}=1: 12)\end{array}$ & 16 & 34 & - & 228 & 269 & 322 \\
\hline $\begin{array}{c}9 \\
\text { (DOPDEDHB:EC = 1:16) }\end{array}$ & 19 & 34 & - & 230 & 255 & 302 \\
\hline $\mathrm{AU}: \mathrm{EC}=1: 6[19]$ & 7 & 23 & 33 & 260 & 320 & 550 \\
\hline AU:EC:PO = 1:6:6 [20] & 13 & 29 & 41 & 235 & 280 & 330 \\
\hline
\end{tabular}

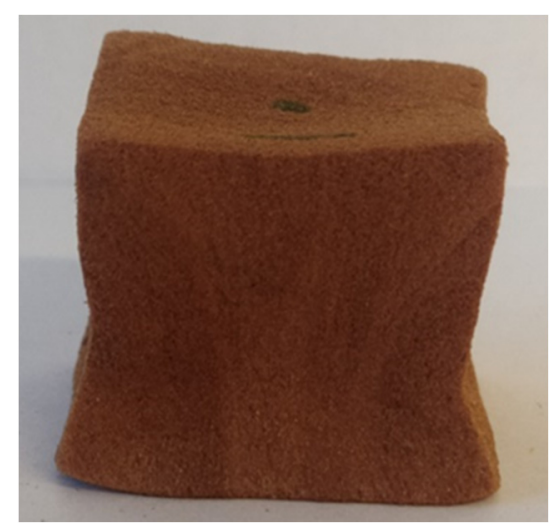

Figure 7. Composition 7 after exposition at temperature $175^{\circ} \mathrm{C}$.

The gradual loss of mass was observed, but the highest loss of mass of foams was always observed after the first day of exposition. Stabilization of mass was reached after 23-25 days. The mass losses of foams after exposition at temperatures of $150{ }^{\circ} \mathrm{C}$ and $175^{\circ} \mathrm{C}$ for 30 days were $16-24 \mathrm{wt} . \%$ and 34-38 wt. $\%$, respectively (Table 6). All foams after thermal treatment became more rigid. Dynamic thermal analysis showed that $10 \%$ mass loss was observed at temperature range $202-235{ }^{\circ} \mathrm{C}$ and $50 \%$ mass loss at $299-322{ }^{\circ} \mathrm{C}$ (Table 6). The research indicates that polyurethane foams prepared from oligoetherols synthesized from $\mathrm{BHEU}, \mathrm{BA}$, and EC are characterized by better thermal resistance than classic industrial polyurethane foams and worse than foams based on oligoetherols from $\mathrm{AU}$ and $\mathrm{EC}$ or from AU, EC, and PO (Table 6).

The thermal conductivity coefficients of the obtained materials fell in the range $0.0349-0.0368 \mathrm{~W} /(\mathrm{m} \times \mathrm{K})$ (Table 7). These were larger in comparison with typical rigid polyurethane foams $(0.019-0.026 \mathrm{~W} /(\mathrm{m} \times \mathrm{K}))[10]$, but still indicate good thermal insulation properties of boron-modified foams. 
Table 7. Thermal conductivity and compression strength of selected polyurethane foams.

\begin{tabular}{|c|c|c|c|c|}
\hline \multirow{3}{*}{$\begin{array}{l}\text { Composition Number } \\
\text { (From Oligoetherol) }\end{array}$} & \multirow{3}{*}{$\begin{array}{c}\text { Thermal Conductivity } \\
\text { Coefficient } \\
\Lambda \\
{[\mathrm{W} / \mathrm{m} \times \mathrm{K}]}\end{array}$} & \multicolumn{3}{|c|}{ Compression Strength } \\
\hline & & \multicolumn{2}{|c|}{ Before Exposition } & \multirow{2}{*}{$\begin{array}{c}\text { After Exposition at } 150^{\circ} \mathrm{C} \\
\sigma_{10} \\
(\mathrm{MPa})\end{array}$} \\
\hline & & $\begin{array}{c}\sigma_{M} \\
(\mathrm{MPa})\end{array}$ & $\begin{array}{l}\varepsilon_{M} \\
(\%)\end{array}$ & \\
\hline $\begin{array}{c}2 \\
\text { (BHEU:BA:EC }=1: 2: 12)\end{array}$ & 0.0357 & 0.33 & 7.08 & 0.58 \\
\hline $\begin{array}{c}4 \\
\text { (BHEU:BA:EC = 1:3:12) }\end{array}$ & 0.0368 & 0.30 & 7.99 & 0.81 \\
\hline $\begin{array}{c}7 \\
(\text { DOPDEDHB:EC }=1: 12)\end{array}$ & 0.0357 & 0.29 & 8.33 & 1.12 \\
\hline $\begin{array}{c}9 \\
\text { (DOPDEDHB:EC = 1:16) }\end{array}$ & 0.0349 & 0.32 & 9.08 & 1.27 \\
\hline
\end{tabular}

$\sigma_{\mathrm{M}}$-compression strength, $\varepsilon_{\mathrm{M}}$ —strain, $\sigma_{10}$-compression strength at $10 \%$ strain.

Mechanical properties were evaluated on the basis of compression strength measurements (Table 7). Before the thermal treatment, compression strengths of the foams were in the range of $0.29-0.33 \mathrm{MPa}$. It has been observed that one-month-long thermal treatment at temperature $150{ }^{\circ} \mathrm{C}$ resulted in higher compression strengths $(0.58-1.27 \mathrm{MPa})$. This is presumably related to structural changes of polyurethane foams. During exposition at the temperature of $150^{\circ} \mathrm{C}$, the process of additional cross-linking of the foams probably occurred, and the material degradation had not taken place yet. The foam based on oligoetherol obtained from DOPDEDHB and 16 moles of EC was characterized by the highest compressive strength $(1.27 \mathrm{MPa})$ after exposition at $150{ }^{\circ} \mathrm{C}$. The tested foams resisted significantly higher forces than the foams based on obtained oligoetherol from $\mathrm{AU}$ and 6 moles EC (0.14 MPa) [19].

Flammability of the foams was determined by the methods of horizontal burning test and oxygen index (Table 8). The horizontal burning test showed that all the foams were self-extinguishing in the air. In the horizontal test, the flame reached merely in the range $11-20 \mathrm{~mm}$ from the ignition start point, and the flaming rate was in the range 2.06-3.42 mm/s (Table 8). Mass losses during burning amounted to $3.81 \mathrm{wt} \%$ (composition No. 4) up to $4.97 \mathrm{wt} . \%$. (composition No. 9). The oxygen index of the obtained foams had values in the range of $22.0-24.1 \mathrm{vol} \%$ (Table 8 ) The limit value of the oxygen index (LOI) distinguishes three classes of flammability of materials: flammable-LOI $<21 \%$, fire retardant-LOI $=21-28 \%$, and nonflammable-LOI $>28 \%$ [1]. Thus, the obtained foams can be classified as class two. The foams with the highest boron content (composition No. 4) presented the lowest flammability. The flammability tests indicated that the obtained polyurethane foams with 1,3-pyrimidine ring and boron atoms are self-extinguishing and flame-retardant [43].

Table 8. Horizontal burning tests and oxygen index of selected polyurethane foams.

\begin{tabular}{|c|c|c|c|c|}
\hline \multirow{2}{*}{$\begin{array}{l}\text { Composition Number } \\
\text { (From Oligoetherol) }\end{array}$} & \multicolumn{3}{|c|}{ Horizontal Burning Tests } & \multirow[b]{2}{*}{ Oxygen Index (vol\%) } \\
\hline & $\begin{array}{c}\text { Linear Burning Rate } \\
(\mathrm{mm} / \mathrm{s})\end{array}$ & $\begin{array}{l}\text { Distance Burnt } \\
(\mathrm{mm})\end{array}$ & $\begin{array}{l}\text { Mass Loss During } \\
\text { Burning ( } \% \text { mas. })\end{array}$ & \\
\hline $\begin{array}{c}2 \\
\text { (BHEU:BA:EC }=1: 2: 12)\end{array}$ & 3.42 & 18 & 4.35 & 22.3 \\
\hline $\begin{array}{c}4 \\
\text { (BHEU:BA:EC = 1:3:12) }\end{array}$ & 2.06 & 11 & 3.81 & 24.1 \\
\hline $\begin{array}{c}7 \\
\text { (DOPDEDHB:EC = 1:12) }\end{array}$ & 2.05 & 13 & 3.84 & 22.1 \\
\hline $\begin{array}{c}9 \\
\text { (DOPDEDHB:EC = 1:16) }\end{array}$ & 2.68 & 20 & 4.97 & 22.0 \\
\hline
\end{tabular}


Polyurethane foams obtained from oligoetherols synthesized from 1,3-bis(2-hydroxyethyl)uracil, boric acid, and ethylene carbonate characterized a reduced flammability and improved thermal stability compared to classic, rigid polyurethane foams.

\section{Conclusions}

Oligoetherols obtained from 1,3-bis(2-hydroxyethyl)uracil, boric acid, and ethylene carbonate are suitable for manufacturing of polyurethane foams with improved thermal stability and reduced flammability. The obtained polyurethane foams have better thermal resistance than the resistance of classic polyurethane foams and can be used at a temperature range of $150-175{ }^{\circ} \mathrm{C}$. Total mass losses of $10 \%$ were observed in the foams in the temperature range of $202-235^{\circ} \mathrm{C}$. The water absorption rates of these foams were larger than the water absorption of commercial foams and after $24 \mathrm{~h}$ of exposition they were within the range $8.05-27.62 \mathrm{vol} \%$. This fact is due to the presence of boron and the formation of a coordination bond between the water oxygen atom and the boron atom. The other properties of foams, such as, apparent density, dimensions stability, thermal conductivity, and compression strength were similar to the properties of the commercial polyurethane foams. The apparent density rates of the foams were in the range of $56-91 \mathrm{~kg} / \mathrm{m}^{3}$, the thermal conductivity levels fell in the range $0.0349-0.0368 \mathrm{~W} /(\mathrm{m} \times \mathrm{K})$, compression strength values were in the range of $0.29-0.33 \mathrm{MPa}$. The compression strengths of foams after exposition at temperature $150{ }^{\circ} \mathrm{C}$ for 30 days increased to $0.58-1.27 \mathrm{MPa}$. The oxygen indexes of the foams were in the range of $22.0-24.1 \mathrm{vol} \%$, hence the obtained materials were hardly flammable under normal atmospheric conditions, in contrast to foams based on oligoetherols obtained from $\mathrm{AU}$ and $\mathrm{EC}$ or from $\mathrm{AU}, \mathrm{EC}$, and $\mathrm{PO}$, without the addition of boron.

Funding: This research received no external funding.

Data Availability Statement: The data that support the findings of this study are available from the corresponding author upon reasonable request.

Conflicts of Interest: The authors declare no conflict of interest.

\section{References}

1. Prociak, A.; Rokicki, G.; Ryszkowska, J. Polyurethane Materials; Wydawnictwo Naukowe PWN: Warsaw, Poland, 2016. (In Polish)

2. Tan, S.; Abraham, T.; Ference, D.; Macosko, C.W. Rigid polyurethane foams from a soybean oil-based polyol. Polymer 2011, 52, 2840-2846. [CrossRef]

3. Veronese, V.B.; Menger, R.K.; Forte, M.M.; Petzhold, C.L. Rigid polyurethane foam based on vegetable oil. J. Appl. Polym. Sci. 2011, 120, 530-537. [CrossRef]

4. Gaidukov, S.; Maksimov, R.D.; Cabulis, U.; Plume, E.; Stunda-Zujeva, A. Mechanical properties of a rigid polyurethane/montmorillonite composite prepared by using a biopolyol. Mech. Compos. Mater. 2013, 49, 333-344. [CrossRef]

5. Gaidukovs, S.; Kampars, V.; Bitenieks, J.; Bochkov, I.; Gaidukova, G.; Cabulis, U. Thermo-mechanical properties of polyurethane modified with graphite oxide and carbon nanotube particles. Integr. Ferroelectr. 2016, 173, 1-11. [CrossRef]

6. Luo, X.; Li, Y. Synthesis and Characterization of Polyols and Polyurethane Foams from PET Waste and Crude Glycerol. J. Polym. Environ. 2014, 22, 318-328. [CrossRef]

7. Kuranska, M.; Prociak, A. The influence of rapeseed oil-based polyols on the foaming process of rigid polyurethane foams. Ind. Crops Prod. 2016, 89, 182-187. [CrossRef]

8. Kuranska, M.; Prociak, A.; Cabulis, U.; Kirpluks, M.; Ryszkowska, J.; Auguscik, M. Innovative porous polyurethanepolyisocyanurate foams based on rapeseed oil and modified with expandable graphite. Ind. Crops Prod. 2017, 95, 316-323. [CrossRef]

9. Gaidukova, G.; Ivdre, A.; Fridrihsone, A.; Verovkins, A.; Cabulis, U.; Gaidukovs, S. Polyurethane rigid foams obtained from polyols containing bio-based and recycled components and functional additives. Ind. Crops Prod. 2017, 102, 133-143. [CrossRef]

10. Borowicz, M.; Paciorek-Sadowska, J.; Lubczak, J.; Czupryński, B. Biodegradable, Flame-Retardant, and Bio-Based Rigid Polyurethane/Polyisocyanurate Foams for Thermal Insulation Application. Polymers 2019, 11, 1816. [CrossRef] [PubMed]

11. Czupryński, B. Questions of Chemistry and Technology of Polyurethanes; The Publishing House of the Academy of Bydgoszcz: Bydgoszcz, Poland, 2004. (In Polish)

12. Sawicki, T. Plastics and fire hazard. Work Saf. 2003, 7-8, 43-45. (In Polish)

13. Liu, X.; Hao, J.; Gaan, S. Recent studies on the decomposition and strategies of smoke and toxicity suppression for polyurethane based materials. RSC Adv. 2016, 6, 74742-74756. [CrossRef] 
14. Kijowska, D.; Kucharski, M. Polyetherols from melamine and alkylene carbonates: Properties and application of foamed polyurethanes. J. Appl. Polym. Sci. 2004, 94, 2302-2308. [CrossRef]

15. Lubczak, J.; Chmiel-Szukiewicz, E.; Duliban, J.; Głowacz-Czerwonka, D.; Lubczak, R.; Łukasiewicz, B.; Zarzyka, I.; Łodyga, A.; Tyński, P.; Minda-Data, D.; et al. Polyurethane foams with 1,3,5-triazine ring of improved thermal stability. Przem. Chem. 2014, 10, 1690-1697. (in Polish) [CrossRef]

16. Cisek-Cicirko, I.; Lubczak, J. Polyurethane Foams of Improved Thermal Stability. Macromol. Mater. Eng. 2002, 287, 665-670. [CrossRef]

17. Lubczak, J. Polyurethane foams with purine rings. Polimery 2007, 52, 595-600. [CrossRef]

18. Chmiel-Szukiewicz, E. Polyurethane foams with 1,3-pyrimidine ring. J. Appl. Polym. Sci. 2008, 109, 1708-1713. [CrossRef]

19. Chmiel-Szukiewicz, E. Polyurethane foams based on polyetherols obtained from 6-aminouracil and alkylene carbonates. Polimery 2010, 55, 817-824. [CrossRef]

20. Chmiel-Szukiewicz, E. New foamed plastic based polyetherols obtained from 6-aminouracil, ethylene carbonate and propylene oxide. J. Appl. Polym. Sci. 2013, 127, 1595-1600. [CrossRef]

21. Kania, E.; Lubczak, J. Polyurethane Foams with Pyrimidine Rings. Pol. J. Chem. Technol. 2014, 16, 1-6. [CrossRef]

22. Lu, S.Y.; Hamerton, I. Recent developments in the chemistry of halogenfree flame retardant polymers. Prog. Polym. Sci. 2002, 27, 1661-1712. [CrossRef]

23. Chen, M.J.; Chen, C.R.; Tan, Y.; Huang, J.Q.; Wang, X.L.; Chen, L.; Wang, Y.Z. Inherently Flame-Retardant Flexible Polyurethane Foam with Low Content of Phosphorus-Containing Cross-Linking Agent. Ind. Eng. Chem. Res. 2014, 53, 1160-1171. [CrossRef]

24. Zhu, H.; Peng, Z.; Chen, Y.; Li, G.; Wang, L.; Tang, Y.; Pang, R.; Khan, Z.U.H.; Wan, P. Preparation and characterization of flame retardant polyurethane foams containing phosphorus-nitrogen-functionalized lignin. RSC Adv. 2014, 4, 55271-55279. [CrossRef]

25. La Guardia, M.J.; Hale, R.C. Halogenated flame-retardant concentrations in settled dust, respirable and inhalable particulates and polyurethane foam at gymnastic training facilities and residences. Environ. Int. 2015, 79, 106-114. [CrossRef]

26. Czupryński, B.; Paciorek-Sadowska, J.; Liszkowska, J. Modifications of the rigid polyurethane-polyisocyanurate foams. J. Appl. Polym. Sci. 2006, 100, 2020-2029. [CrossRef]

27. Paciorek-Sadowska, J.; Czupryński, B. New Compounds for Production of Polyurethane Foams. J. Appl. Polym. Sci. 2006, 102, 5918-5926. [CrossRef]

28. Paciorek-Sadowska, J.; Czupryński, B.; Liszkowska, J. New polyol for production of rigid polyurethane-polyisocyanurate foams. Part 2: Preparation of rigid polyurethane-polyisocyanurate foams with the new polyol. J. Appl. Polym. Sci. 2010, 118, $2250-2256$. [CrossRef]

29. Paciorek-Sadowska, J.; Czupryński, B.; Liszkowska, J. Boron-containing fire retardant rigid polyurethane-polyisocyanurate foams: Part II-Preparation and evaluation. J. Fire Sci. 2015, 33, 48-68. [CrossRef]

30. Lubczak, J.; Łukasiewicz, B. Oligoetherols and polyurethane foams with 1,3,5-triazine ring and boron. Polimery 2012, 57, 819-829. [CrossRef]

31. Lubczak, J.; Łukasiewicz, B.; Myśliwiec, B. Synthesis and applications of oligoetherols with perhydro-1,3,5-triazine ring and boron. J. Appl. Polym. Sci. 2013, 127, 2057-2066. [CrossRef]

32. Chmiel, E.; Lubczak, J. Oligoetherols and polyurethane foams obtained from melamine diborate. J. Polym. Res. 2017, 24, 95. [CrossRef]

33. Chmiel, E.; Lubczak, J.; Stagraczyński, R. Modification of polyurethane foams with 1,3,5-triazine ring and boron. Macromol. Res. 2017, 25, 317-324. [CrossRef]

34. Chmiel-Szukiewicz, E. Method for Producing 1,3-bis(2-hydroxyethyl)uracil. Polish Patent 230024, 28 September 2018.

35. Sekuła, J.; Nizioł, J.; Rode, W.; Ruman, T. Gold nanoparticleenhanced target (AuNPET) as universal solution for laser desorption/ionization mass spectrometry analysis and imaging of low molecular weight compounds. Anal. Chim. Acta 2015, 875, 61-72. [CrossRef] [PubMed]

36. Cellular Plastics and Rubbers_Determination of Apparent (Bulk) Density; Polish (European) Standards PN-EN ISO 845:2010; Polish Committee for Standardization: Warsaw, Poland, 2010.

37. Cellular Plastics, Rigid-Determination of Water Absorption; Polish (European) Standards PN-EN ISO 2896:1987; Polish Committee for Standardization: Warsaw, Poland, 1987.

38. Cellular Plastics, Rigid-Test of Dimensional Stability; Polish (European) Standards PN-EN ISO 2796:1986; Polish Committee for Standardization: Warsaw, Poland, 1986.

39. Thermal Insulation Products for Buildings_Factory Made Rigid Polyurethane Foam (PU) Products—Specification; Polish (European) Standards PN-EN 13165:2009; Polish Committee for Standardization: Warsaw, Poland, 2009.

40. Cellular Plastics, Compression Test for Rigid Materials; Polish (European) Standards PN- EN ISO 844-1978; Polish Committee for Standardization: Warsaw, Poland, 1978.

41. Cellular Plastics. Determination of Horizontal Burning Characteristics of Small Specimens Subjected to a Small Flame; European Standards ISO 9772:2012; Polish Committee for Standardization: Warsaw, Poland, 2012.

42. Plastics-Determination of Burning Behaviour by Oxygen Index-Ambient-Temperature Test; Polish (European) Standards PN ISO 4589-2:1999; Polish Committee for Standardization: Warsaw, Poland, 1999.

43. Flexible Cellular Polymeric Materials_Laboratory Characteristics of Small Specimens Subject to a Small Flame; Polish (European) Standards PN-EN ISO 3582-2002; Polish Committee for Standardization: Warsaw, Poland, 2002. (In Polish) 